\title{
The influence of land cover roughness on the results of high resolution tsunami inundation modeling
}

\author{
G. Kaiser ${ }^{1}$, L. Scheele ${ }^{1}$, A. Kortenhaus ${ }^{2}$, F. Løvholt ${ }^{3}$, H. Römer ${ }^{1, *}$, and S. Leschka ${ }^{4}$ \\ ${ }^{1}$ Institute of Geography, Christian-Albrechts-Universität zu Kiel, Germany \\ ${ }^{2}$ Leichtweiß - Institute for Hydraulic Engineering and Water Resources, Technische Universität Braunschweig, Germany \\ ${ }^{3}$ Norwegian Geotechnical Institute, Oslo, Norway \\ ${ }^{4}$ DHI-NTU Research Centre and Education Hub, Singapore \\ *now at: German Remote Sensing Data Center (DFD), German Aerospace Center (DLR), Oberpfaffenhofen, Germany
}

Received: 22 April 2011 - Accepted: 10 June 2011 - Published: 22 September 2011

\begin{abstract}
In this paper a local case study is presented in which detailed inundation simulations have been performed to support damage analysis and risk assessment related to the 2004 tsunami in Phang Nga and Phuket, Thailand. Besides tsunami sources, bathymetry and topography, bottom roughness induced by vegetation and built environment is considered to influence inundation characteristics, such as water depths or flow velocities and therefore attracts major attention in this work. Plenty of information available on the 2004 tsunami event, high-resolution satellite imagery and extensive field measurements to derive land cover information and forest stand parameters facilitated the generation of topographic datasets, land cover maps and site-specific Manning values for the most prominent land cover classes in the study areas. The numerical models ComMIT and Mike 21 FM were used to hindcast the observed tsunami inundation and to draw conclusions on the influence of land cover on inundation patterns. Results show a strong influence of dense vegetation on flow velocities, which were reduced by up to $50 \%$ by mangroves, while the inundation extent is influenced only to a lesser extent. In urban areas, the disregard of buildings in the model led to a significant overestimation of the inundation extent. Hence different approaches to consider buildings were used and analyzed in the model. The case study highlights the importance and quantifies the effects of considering land cover roughness in inundation simulations used for local risk assessment.
\end{abstract}

Correspondence to: G. Kaiser (kaiser@geographie.uni-kiel.de)

\section{Introduction}

The disaster which evolved from the 2004 Indian Ocean tsunami pointed out the tremendous impacts of extreme flooding by devastating vast coastal areas around the Indian Ocean. The southern coastal provinces of Thailand were among the most heavily impacted areas, where 8345 people lost their lives, 67007 were affected and the economic losses added up to about $\$ 2$ billion USD (United Nations and World Bank, 2005; EM-DAT, 2010). Beyond that, the affected regions suffered from social and environmental impacts (Cochard et al., 2007; Szczucinski et al., 2006; United Nations and World Bank, 2005). As a consequence of this event, a large number of projects and research activities have been launched to investigate hazard mechanisms and vulnerabilities that led to the disaster and to develop methodologies to mitigate future tsunami impacts by improving risk assessment, early warning and management in flood prone coastal areas bordering the Indian Ocean and beyond (e.g. Borrero et al., 2006; Ioualalen et al., 2007; Jakeman et al., 2007; McCloskey et al., 2008; Okal and Synolakis, 2008; Rudloff et al., 2009; Spahn et al., 2010; Taubenböck et al., 2009).

To understand and predict tsunami wave propagation and inundation within the framework of a risk assessment, numerical modeling is an important tool (Ioualalen et al., 2007). Detailed numerical simulations provide information on inundation patterns and thus support early warning, evacuation planning and vulnerability analyses (Taubenböck et al., 2009). However, inundation processes are difficult to model due to complex interactions at the shore and on land (Dalrymple et al., 2006).

Published by Copernicus Publications on behalf of the European Geosciences Union. 
Several studies have been conducted to model the 2004 tsunami at the coasts of Thailand (e.g. Grilli et al., 2007; Ioualalen et al., 2007; Kawata et al., 2005; Løvholt et al., 2006). These studies focus on modeling wave propagation, tsunami magnitude and arrival time at the coast as well as run up. Moreover, some detailed site-specific studies have been performed modeling inundation to investigate certain hazard mechanism and impacts. For example, Yanagisawa et al. (2009) used numerical simulations to investigate wave attenuation of mangroves in Khao Lak, to derive fragility functions for mangrove trees, and to estimate the probability of their damage subject to a tsunami. Recently also Suppasri et al. (2011) modeled inundation for Khao Lak and Patong Beach to determine the structural fragility of buildings against tsunamis based on satellite images taken before and after the 2004 tsunami. Goto et al. (2007) used a detailed inundation simulation to understand the transport processes of boulders at Cape Pakarang, Khao Lak, and Jakeman et al. (2010) analyzed inundation in Patong Beach, taking especially buildings into account.

To produce inundation simulations sufficiently detailed for hazard maps to serve as a basis for efficient risk mitigation measures on a local scale, the sources of errors and uncertainties in the model and the underlying data have to be considered. These stem from the tsunami sources, numerical constraints, as well as the near-shore bathymetry and topography. For detailed tsunami inundation modeling very accurate data on bathymetry and topography are necessary (Schlurmann et al., 2011; Taubenböck et al., 2009). Moreover, an inaccurate or unknown representation of the surface roughness induced by vegetation and built environment may lead to inaccurate simulations (Gayer et al., 2010; Jakeman et al., 2010). Many authors argue, for example, that coastal forests like mangroves or casuarina forests attenuate wave energy to some extent (Dahdouh-Guebas et al., 2005; Danielsen et al., 2005; Kathiresan and Rajendran, 2005; Mazda et al., 1997; Wolanski, 2007) and might thus influence inundation patterns, while others request more data and more research on that topic to really prove this statement (Kerr et al., 2006; Kerr and Baird, 2007). The role of land cover roughness in influencing the dynamics of overland flow is highlighted by Imamura (2009), Leschka et al. (2009), and Gayer et al. (2010) who developed roughness maps for three local sites in Indonesia, finding that land cover roughness significantly influences inundation and therefore proposing to account for these effects as accurately as possible.

Furthermore, it is widely discussed in the literature that buildings and structures in urban areas may act as barriers and thus influence inundation. Investigations on the influence of buildings and on how to account for them in numerical simulations have been conducted by Gayer et al. (2010), Jakeman et al. (2010), Liu et al. (2002), Schlurmann et al. (2011), and Taubenböck et al. (2009). Jakeman et al. (2010) analyzed the influence of buildings in a hydrodynamic model for Patong Beach, Thailand, concluding that urban areas act as dissipaters reducing the volume of water onshore, while increasing flow velocities between buildings. Taubenböck et al. (2009) simulated inundation in Padang using a digital surface model as well as an elevation model combined with a house mask to study the effects of obstacles and roughness. They concluded that both reduce the inundation extent compared to applying only bare ground elevation data. Moreover, they also found that water is channeled in the streets when applying high-resolution data.

The work presented in this paper is part of the bilateral research project TRAIT (Tsunami Risks, Vulnerability and Resilience in the Phang-Nga and Phuket Provinces, Thailand). In TRAIT, extensive field investigations and surveys have been conducted and high-resolution geo-data have been used to analyze the impact mechanisms and recovery processes of the 2004 tsunami. The aim was to better understand tsunami risk on a local scale, enhance tools and methodologies for local risk assessment and eventually contribute to risk mitigation in coastal communities in the Phang Nga and Phuket Provinces in Thailand. As part of a tsunami hazard analysis in TRAIT, this paper deals with local effects resulting from inundation modeling, which are considered to be relevant for tsunami risk assessment and mitigation.

A large amount of high-resolution data available for the study areas together with validation data of the 2004 tsunami allowed us to hindcast the event and to conduct a case study to further analyze the required quality and influence of highresolution data, vegetation, and buildings on inundation simulations. Moreover, the inundation simulations described in this paper provide information on the interrelation between inundation patterns and damages that occurred in Thailand, as well as for an overall risk and vulnerability assessment in the TRAIT project. The aims of this case study were to: (i) produce the geo-data relevant for high- resolution inundation modeling, (ii) model the 2004 tsunami for Thailand, (iii) determine site-specific Manning values for land cover classes at the Phang Nga coast of Thailand, (iv) study the effect of coastal vegetation on inundation patterns using a numerical inundation model, (v) analyze the influence of buildings on inundation patterns in rural and dense urban areas, and (vi) deduce implications for risk assessment and management from the results.

The paper is structured as follows: a description of the preparation of the input data is given in Sect. 3. Section 4 describes the methodology and the models used for the tsunami simulations. Section 5 illustrates and describes the results, and a final discussion of the relevant findings is provided in Sect. 6.

\section{Study areas}

Three local study areas have been chosen, all of which significantly differ in their topography, vegetation and settlement structure: Ban Nam Khem, Khao Lak and Patong Beach, located at the Andaman Sea coast of Thailand (Fig. 1). 

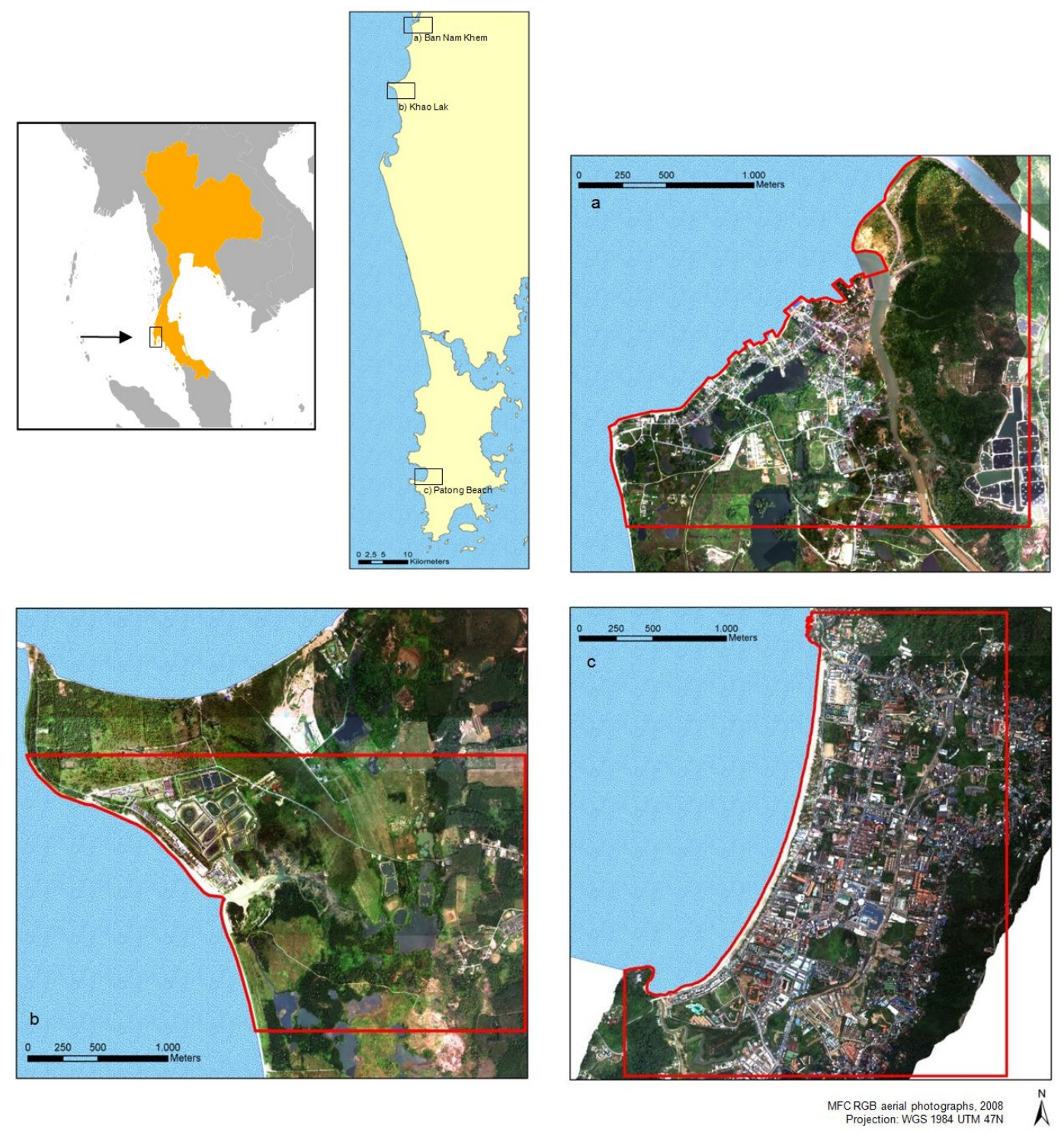

Fig. 1. Study areas (a) Ban Nam Khem, (b) Khao Lak and (c) Patong Beach at the Andaman Sea coast of Thailand (aerial images from MFC system, obtained and processed by DLR/RSS).

The Ban Nam Khem area (Fig. 1a) allows for analyzing inundation patterns in a rural landscape. Ban Nam Khem is a fishing village located in a flat area with a ground elevation of approximately $2-3 \mathrm{~m}$, in some areas higher than $6 \mathrm{~m}$. Several ponds are located in the village. The housing density is relatively low and the houses are mainly of poor quality, only partly built of stone, often constructed from simple materials such as corrugated plates. In contrast, Khao Lak (Fig. 1b) is a booming tourist centre, with sparsely distributed resorts in a hilly area. The area is characterized by several tidal inlets and large patches of dense tropical vegetation like mangroves, casuarinas forests, or coconut plantations. Khao Lak was the most heavily impacted area in Thailand during the 2004 tsunami, in which $80 \%$ of the hotel capacity was lost
(Mård Karlsson et al., 2009). The study area located south of Pakarang Cape comprises the largest mangrove patch in Khao Lak, a tidal inlet, aquaculture, coastal forests and hotel resorts. Patong Beach on Phuket Island (Fig. 1c) represents a densely populated and urbanized community. The whole city lies approximately 3-4 m above mean sea level (msl). Videos taken during the 2004 tsunami showed that the dense structure of resistant buildings led to a major flood impact in the first road parallel to the shore and a channel effect in the streets perpendicular to the coast, conducting the water further into the town. Contrary to Khao Lak and Ban Nam Khem, in Patong Beach the role of resistant buildings in inundation simulations is relevant. The size of the study areas differs from 355 ha in Ban Nam Khem to 462 ha in Khao Lak, 
and 545 ha in Patong Beach. These extents were chosen in order to allow for maximum resolution of the elevation data in the numerical model.

\section{Data}

We prepared three input data sets to represent the landscape characteristics in the study areas, which are considered to influence local inundation patterns: (a) a detailed description and spatial distribution of land use/land cover classes, (b) site-specific roughness information for each land cover class, and (c) high-resolution digital elevation models. Since the accuracy of these data is a prerequisite for detailed inundation simulations in the following section the generation of the data sets is described.

\subsection{Land cover classification}

The spreading of water on land is mainly directed by local topography but also to some extent by land cover, such as forests, water bodies or built environment. Thus, at first, detailed maps providing information on the spatial characteristics of land use and land cover (lulc) in the study areas were derived from high-resolution Ikonos satellite images $(4 \mathrm{~m}$ in the multispectral channels). Due to the tsunami waves washing away coastal forests and settlement structures, land cover changed during the tsunami. This lulc-change may have led to altered buffer effects and thus might influence inundation risk in the aftermath of the 2004 event. We considered this aspect in our study by producing two different lulc-maps from Ikonos imagery from January 2003 (pre-tsunami) and January 2005 (post-tsunami).

The lulc classification was performed using the software Definiens Developer version 7.0 (www.definiens.com), and is described briefly in the following. More details on the procedure can be found in Baatz and Schäpe (2000), Definiens (2007), and Weidner and Lemp (2005). A rulebased, object-oriented classification scheme was applied to extract lulc-information from the multi-spectral images of 2003. Two hierarchical levels were applied: a lower segmentation level (multi-resolution segmentation) to classify small landscape objects, such as single trees, single shadows or buildings and a second higher level to classify all the different lulc-classes occurring on the image. Image segmentations were used flexibly and adjusted according to the respective lulc-class to be extracted. Several single segmentation processes could be realized within the same hierarchical level. Therefore, a typical sequence of process steps in the upper level was (a) image segmentation, (b) rule-based classification of lulc classes, (c) a classification and merging of the unclassified segments and (d) a new segmentation of the merged unclassified segments. Furthermore, class-specific information for the lower segmentation level (sub-level information) was included in the rule set, in order to classify high textured areas such as coconut plantations or urban areas. Here, a typical sub-level feature, the "number of subobjects classified as medium round shadow/number of subobjects", was used in order to consider the typical textural characteristics of a palm plantation.

The final pre-tsunami (2003) classification for the study areas includes the following land cover classes: (1) agriculture and aquaculture: plantations, orchards and aquaculture, (2) barren land: sandy beaches, sand mining, mudflats, (3) buildings and infrastructure, (4) grassland and herbaceous vegetation: dense and sparse grassland with scattered trees, (5) scrubland, (6) semi-open landscapes: mixture of woodland, scrubland and grassland, comparable to savannahs, (7) water: water surfaces like ponds, rivers, bays, (8) woodland: different types of natural forests, e.g. mangroves, casuarina forest, beach forest, primary rain forest, (9) other: clouds, shadows and no data values. With an overall accuracy of $93.6 \%$ and a Kappa of 0.9, the classification result can be considered as very accurate. The map with land cover changes as of January 2005 (post-tsunami) was derived by digital change detection (direct multi-date classification). The land cover maps with $4 \mathrm{~m}$ resolution serve as a data basis for the generation of roughness maps (Sect. 3.2).

\subsection{Land cover roughness}

Land cover information had to be transferred into the numerical model to account for it in the inundation simulation. In non-linear shallow water models, the wave attenuation caused by land cover is expressed as bottom roughness, which is usually interpreted by either Chezy numbers $\left(\mathrm{m}^{1 / 2} \mathrm{~s}^{-1}\right)$, Manning values $\left(\mathrm{m}^{1 / 3} \mathrm{~s}^{-1}\right)$ or through the Manning numbers $n$ (reciprocal of Manning values). Thus, to represent the bottom roughness in the inundation simulation, a method has been developed to calculate the appropriate Manning's roughness coefficients for each land cover class in the study areas.

For this purpose, a formula for deriving Manning's $n$ developed and tested by Petryk and Bosmajian (1975) has been applied (Eq. 1). As this formula requires information on vegetation characteristics, field investigations were conducted in the study areas in January/February 2009 to measure forest stand parameters for the main land cover classes: oil palm plantations, coconut plantations, rubber plantations, casuarina forest, inner and outer beach forest, as well as mangroves (Arp, 2009). Based on the work of Shuto (1987), Tanaka et al. (2007) and the approach described in Arcement and Schneider (1989) the forest stand parameters diameter at breast height (dbh), height of trees, trunk area, branch/leave area, and the density of trees estimated by the number of trees per sample site, were measured for 2-6 sample sites per land cover class (size: $16 \times 16 \mathrm{~m}$, and $32 \times 32 \mathrm{~m}$ for oil and coconut plantations). Petryk and Bosmajian's equation was then applied to calculate Manning's n for each class (Eq. 1). 
$n=n_{0} \sqrt{1+\left(\frac{C_{\mathrm{D}} \sum A_{i}}{2 g A L}\right)\left(\frac{1}{n_{0}}\right)^{2} R^{\frac{4}{3}}}$

where

$$
\begin{aligned}
\left(\frac{\sum A_{i}}{A L}\right)= & \left(\frac{\frac{\sum A_{i(s)}}{s} \times L \times W}{W \times h \times L}\right) \\
& =\left(\frac{\frac{\sum d \mathrm{bh}_{(s)} \times h}{s} \times L \times W}{W \times h \times L}\right)=\frac{\sum d \mathrm{bh}_{(s)}}{s}=\frac{d n_{i}}{s}
\end{aligned}
$$

(Petryk and Bosmajian, 1975), where $n=$ Manning's coefficient, $n_{0}=$ boundary roughness (Arcement and Schneider, 1989); $C_{\mathrm{D}}=$ drag coefficient assumed to equal 1 (Petryk and Bosmajian, 1975; Tanaka et al., 2007); $g=$ gravitational acceleration; $R=$ hydraulic radius, where $R=A / P, A=$ cross-sectional area of flow, $P=$ wetted perimeter; $\sum A_{i}=$ total frontal area of woody vegetation, i.e. originally the projected area of the vegetation in streamwise direction; $\sum A_{i(s)}=$ total average frontal area of woody vegetation per forest type; $\sum d \mathrm{bh}_{(s)}=$ sum of the diameter at breast height per forest type; $s=$ sample site size, $L=$ length of the segment, $W=$ width of the segment, $h=$ inundation depth; $d n_{i}=$ vegetation thickness according to Shuto (1987), where $d=$ average diameter at breast height ( $d \mathrm{bh}$ ), $n_{i}=$ number of individuals.

Finally, the calculated Manning values were assigned to the land cover maps in GIS. To avoid gaps in the final roughness maps, Manning values for the remaining land cover classes in the study areas were estimated based on basic field measurements or taken from literature. Table 1 shows the final Manning values for the study areas. The calculated Manning's $n$ corresponds to an inundation depth of $3 \mathrm{~m}$. In addition to the already described Manning value $n$, its reciprocal $\mathrm{M}\left(\right.$ in $\left.\mathrm{m}^{1 / 3} \mathrm{~s}^{-1}\right)$ is needed for inundation modeling with Mike $21 \mathrm{FM}$ and also shown in Table 1.

Special attention has been given to the land cover change in the mangrove area in Khao Lak. Before the tsunami, a mangrove patch of approximately 26 ha existed south of Cape Pakarang (Figs. 1 and 6). Field studies and multi-temporal satellite analysis of Ikonos images (pre/posttsunami) showed that the area had been reduced to 4.8 ha in the course of the tsunami (Roemer et al., 2010). To investigate the influence of this land cover change on the results of inundation modeling, new roughness values were assigned to the areas according to the land cover classification of 2005 (Table 1). This allows for an analysis of inundation patterns in the area "with" (2003) and "without" (2005) mangroves. Since these mangrove patches have not recovered significantly even five years later (March 2010), this also reflects the current situation in terms of land cover. Besides the loss of mangroves, changes in the hotel complexes could be observed and were included in the new roughness map. As an example, the final roughness map for Khao Lak is shown in Fig. 2.
Table 1. Manning values for land cover classes in the Phang Nga

\begin{tabular}{|c|c|c|c|}
\hline $\begin{array}{l}\text { Land cover } \\
\text { class }\end{array}$ & $\begin{array}{l}\text { Mannings } \\
n\end{array}$ & $\begin{array}{l}\text { Manning } M \\
\text { in } \mathrm{m}^{1 / 3} \mathrm{~s}^{-1}\end{array}$ & Source \\
\hline Barren land/mud, sand, beach, roads & 0.0310 & 32 & $\mathrm{~b}$ \\
\hline Grassland & 0.0360 & 28 & $\mathrm{~b}$ \\
\hline Young Plantation & 0.0370 & 27 & $\mathrm{~b}$ \\
\hline Scrubland & 0.0380 & 26 & $\mathrm{~b}$ \\
\hline Cashew Plantation & 0.0430 & 23 & $\mathrm{~b}$ \\
\hline Other plantation & 0.0430 & 23 & $\mathrm{~b}$ \\
\hline Coconut plantation & 0.0458 & 22 & a \\
\hline Semi open landscape & 0.0550 & 18 & $\mathrm{~b}$ \\
\hline Oil plantation & 0.0573 & 17 & a \\
\hline Middle density urban area & 0.0600 & 17 & $\mathrm{c}, \mathrm{d}$ \\
\hline Melaleuca forest & 0.0550 & 18 & $\mathrm{~b}$ \\
\hline Rubber plantation & 0.0609 & 16 & a \\
\hline Casuarina forest & 0.0731 & 14 & a \\
\hline Inner beach forest & 0.0744 & 13 & a \\
\hline High density urban area & 0.0800 & 12.5 & $\mathrm{c}, \mathrm{d}$ \\
\hline Other forest/rainforest & 0.0850 & 12 & $\mathrm{c}, \mathrm{e}$ \\
\hline Outer beach forest & 0.0870 & 12 & a \\
\hline Mangrove forest & 0.0951 & 11 & a \\
\hline Buildings non-resistant & 0.0900 & 11 & $\mathrm{c}, \mathrm{f}$ \\
\hline Buildings resistant & 0.4000 & 2.5 & $\mathrm{c}, \mathrm{f}$ \\
\hline \multicolumn{4}{|l|}{ Mangrove area 2005 (post-tsunami) } \\
\hline Mangrove $\rightarrow$ water & 0.0110 & 90 & $\mathrm{a}, \mathrm{b}, \mathrm{g}$ \\
\hline Mangrove $\rightarrow$ mud & 0.0310 & 32 & $\mathrm{a}, \mathrm{b}, \mathrm{g}$ \\
\hline Mangrove $\rightarrow$ damaged understory & 0.0310 & 32 & $\mathrm{a}, \mathrm{b}, \mathrm{g}$ \\
\hline Mangrove $\rightarrow$ sand & 0.0310 & 32 & $\mathrm{a}, \mathrm{b}, \mathrm{g}$ \\
\hline Mangrove $\rightarrow$ inclined, roots remaining & 0.0360 & 28 & $\mathrm{a}, \mathrm{b}, \mathrm{g}$ \\
\hline Mangrove $\rightarrow$ no damage & 0.0951 & 11 & $\mathrm{a}, \mathrm{b}, \mathrm{g}$ \\
\hline Mangrove $\rightarrow$ indirect damage & 0.0951 & 11 & $\mathrm{a}, \mathrm{b}, \mathrm{g}$ \\
\hline
\end{tabular}
Province to represent bottom roughness in Mike 21 FM.

Values are derived from ${ }^{\mathrm{a}}$ measurement of tree stand parameters in the field followed by calculation of Manning's $n$ according to Eq. (1); ${ }^{b}$ measurement of stand parameters for different land cover classes in the field and subsequent estimation of Manning's $n ;{ }^{c}$ literature; ${ }^{\mathrm{d}}$ Kotani (1998) in Latief and Hadi (2007); ${ }^{\mathrm{e}}$ Arcement and Schneider (1989); ${ }_{\mathrm{f}}$ Gayer et al. (2010), Leschka et al. (2009); $\mathrm{g}+$ change detection/Ikonos

The city of Patong Beach has been classified into buildings, streets, beach, and barren land. Manning values of $M=32 \mathrm{~m}^{1 / 3} \mathrm{~s}^{-1}$ representing land covered with coarse sand (Gayer et al., 2010) were assigned to streets, beach and barren land. For single building polygons, we followed an approach from Gayer et al. (2010), who used a Manning value of $M=2.5 \mathrm{~m}^{1 / 3} \mathrm{~s}^{-1}$ to represent resistant buildings. The Manning value for non-resistant buildings in Khao Lak and Ban Nam Khem was also derived from the investigations from Gayer et al. (2010) and set to $M=11 \mathrm{~m}^{1 / 3} \mathrm{~s}^{-1}$.

\subsection{Bathymetry and topography}

The bathymetry has been generated by combining two different data sets. For the near-shore zone, digitized nautical charts from the Hydrographic Department of the Royal Thai Navy were used, which are irregularly distributed with a higher density $(\sim 30 \mathrm{~m})$ close to the shore and a decreasing density towards the open sea. In deep water the dataset was complemented by the 30 arc sec General Bathymetric Chart of the Ocean (GEBCO, http://www.gebco.net/data 


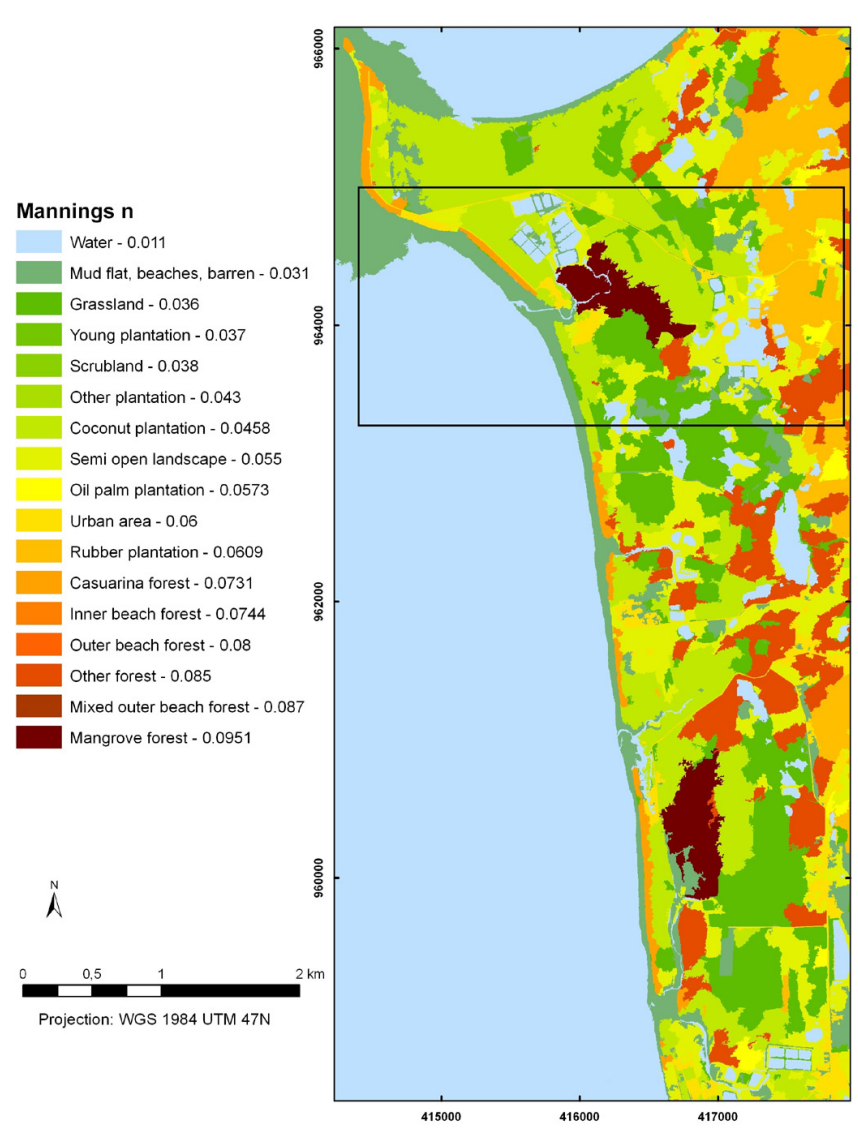

Fig. 2. Roughness map based on an object-oriented land cover classification of a 2003 Ikonos image exemplified for Khao Lak. The study area in Khao Lak is indicated by the black box.

and_products/gridded_bathymetry_data/) to a maximum horizontal grid spacing of $980 \mathrm{~m}$.

In the study areas, the slope of the beach and the elevation vary significantly among different locations. In order to also capture detailed inundation patterns in hilly terrain, rivers, urban areas, and for different land cover types, high-resolution topographic data are required (Goseberg and Schlurmann, 2008; Kongko et al., 2008; Liu et al., 2002). To gather a high-resolution digital elevation model, an airborne flight campaign was conducted in November 2008 using the MFC-3 system from DLR (accomplishment and data processing by the Remote Sensing Solutions GmbH (RSS) and the German Aerospace Center (DLR)). From this, an elevation model with a resolution of $0.15 \mathrm{~m}$ and RGB images could be derived. The original data set derived from the flight campaign is a digital surface model (DSM) describing the Earth's surface including vegetation and settlement. These offsets were significant in our study areas due to tropical forests, so that a correction of the data to a real ground model was required for inundation modeling. To correct these offsets, the data sets were resampled from the original $0.15 \mathrm{~m}$ to a horizontal resolution of $1 \mathrm{~m}$ (due to

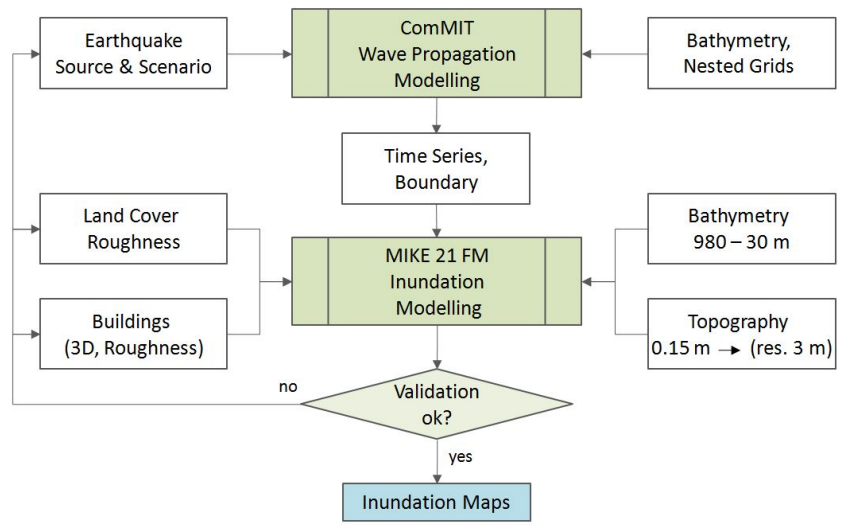

Fig. 3. Input data and methodological approach of the case study.

computational limitations). Land cover offsets were then removed by manual selection of ground control points of the MFC-DSM, visual interpretation of the RGB-imagery and the interpolation between them. Only locations that represent the real terrain were considered as ground control points. A high point density was provided to obtain good results. In Patong Beach, buildings which are resistant in this case were also removed from the original data but then reinserted as a 3-D GIS raster layer with an equal building height of $15 \mathrm{~m}$ above ground. This was done to avoid model instabilities due to the irregular grid cell transitions at buildings occurring in the original DSM. In the corrected elevation models, streets, water bodies, shrimp farms or obstacles could be clearly distinguished (Fig. 12).

\section{Method}

The methodological approach (Fig. 3) included tsunami generation and propagation modeling with the Community Interface Tsunami model, ComMIT (nctr.pmel.noaa.gov/ ComMIT/) and subsequent inundation modeling with the Mike 21 Flexible Mesh Hydrodynamic Module (Mike 21 FM, DHI, http://mikebydhi.com/). Both models were connected at an offshore boundary, where time series of the ComMIT propagation run provided an open west boundary for the Mike inundation modeling.

\subsection{Earthquake seabed displacement and tsunami propagation modeling}

The ComMIT model is based on the Method of Splitting Tsunami, MOST (Titov and Synolakis, 1995, 1998). The source mechanisms of the Great Sumatra 2004 Earthquake (Table 2) were adapted from Løvholt et al. (2006); however, they are slightly different due to the constraint of the predefined sources in ComMIT. But as the mechanical seabed displacement model in ComMIT is a standard one that also resembles the model in Løvholt et al. (2006), the source implemented herein does not deviate much. For the wave 
Table 2. Scenario earthquake segmentation of the 2004 tsunami event (Løvholt et al., 2006).

\begin{tabular}{rrrrrrrrr}
\hline \multirow{6}{*}{$\begin{array}{r}\text { Rig. } \\
(\mathrm{GPa})\end{array}$} & $\begin{array}{r}L \\
(\mathrm{~km})\end{array}$ & $\begin{array}{r}\mathrm{W} 1-\mathrm{S} \\
(\mathrm{km})\end{array}$ & $\begin{array}{r}\mathrm{W} 2-\mathrm{N} \\
(\mathrm{km})\end{array}$ & $\begin{array}{r}\mathrm{S} 1-\mathrm{S} \\
(\mathrm{m})\end{array}$ & $\begin{array}{r}\mathrm{S} 2-\mathrm{N} \\
(\mathrm{m})\end{array}$ & $\begin{array}{r}\text { Mom. } \\
(\mathrm{Nm})\end{array}$ & $M_{\mathrm{W}}$ \\
\hline \multirow{4}{*}{ M 9.28} & 40 & 182.5 & 210 & 160 & 17.5 & 18 & $2.07 \mathrm{E}+22$ & 8.82 \\
& 40 & 181.2 & 210 & 160 & 17 & 17.5 & $2.00 \mathrm{E}+22$ & 8.81 \\
& 40 & 94 & 160 & 140 & 5 & 5 & $2.82 \mathrm{E}+21$ & 8.24 \\
& 40 & 185 & 140 & 155 & 19 & 15 & $1.84 \mathrm{E}+22$ & 8.78 \\
& 40 & 185 & 155 & 170 & 12 & 19 & $1.88 \mathrm{E}+22$ & 8.79 \\
& 40 & 185 & 170 & 210 & 9.2 & 11.1 & $1.44 \mathrm{E}+22$ & 8.71 \\
& 40 & 189 & 210 & 210 & 6 & 4 & $7.94 \mathrm{E}+21$ & 8.54 \\
\hline
\end{tabular}

propagation model, ComMIT utilizes a set of three nested rectangular grids $(\mathrm{A}, \mathrm{B}, \mathrm{C})$ to compute wave propagation and dry land inundation in the non-linear shallow water approximation. It also includes an overall bottom roughness term formulated using the Manning coefficient $n$. The resolution of the nested grids applied was set to A-grid $=980 \mathrm{~m}$, $\mathrm{B}$-grid $=460 \mathrm{~m}, \mathrm{C}$-grid $=40 \mathrm{~m}$ (note: the $\mathrm{C}$ grid was not considered, since the time series for connecting both models was taken from the B grid). The roughness coefficient was set to $n=0.02$ for the whole model domain. At a water depth of approximately $65-70 \mathrm{~m}$, time series were depicted for each study area to serve as west boundaries for the Mike model (Fig. 4). Figure 4 also shows the surface elevation close to the shore as modeled with Mike.

\subsection{Tsunami inundation modeling}

For inundation modeling the software Mike $21 \mathrm{FM}$ was used. Mike $21 \mathrm{FM}$ solves the two-dimensional incompressible Reynolds-averaged Navier-Stokes equations. An unstructured triangular mesh is used, where the maximum area of each triangle can be prescribed to match existing topographic and/or bathymetric resolutions. The bottom shear stress is determined by a quadratic friction law, where the depth-average velocity and the drag coefficient are determined using Manning values (DHI, 2009).

The bathymetry and the processed elevation data were interpolated onto flexible meshes for each study area using a maximum area of the mesh triangles of $400000 \mathrm{~m}^{2}$ in the open ocean, which decreases to approximately $9 \mathrm{~m}^{2}$ towards the shore. From the coastline to an elevation of $5 \mathrm{~m}$ the triangle area was $9 \mathrm{~m}^{2}$ (based on a $3 \times 3 \mathrm{~m}$ raster, which corresponds to the smallest possible size related to the size of the model grid), and from an elevation of $5 \mathrm{~m}$ upwards the resolution was set to $100 \mathrm{~m}^{2}$. The roughness maps produced from the land cover classification were included as a $2 \times 2 \mathrm{~m}$ raster in the model domain. Bottom roughness of the ocean and the shallow water zone was set to $M=90 \mathrm{~m}^{1 / 3} \mathrm{~s}^{-1}$. While bottom roughness is assumed to be negligible in the deep ocean it should in fact be considered in shallow water (Dao and Tkalich, 2007). However, in
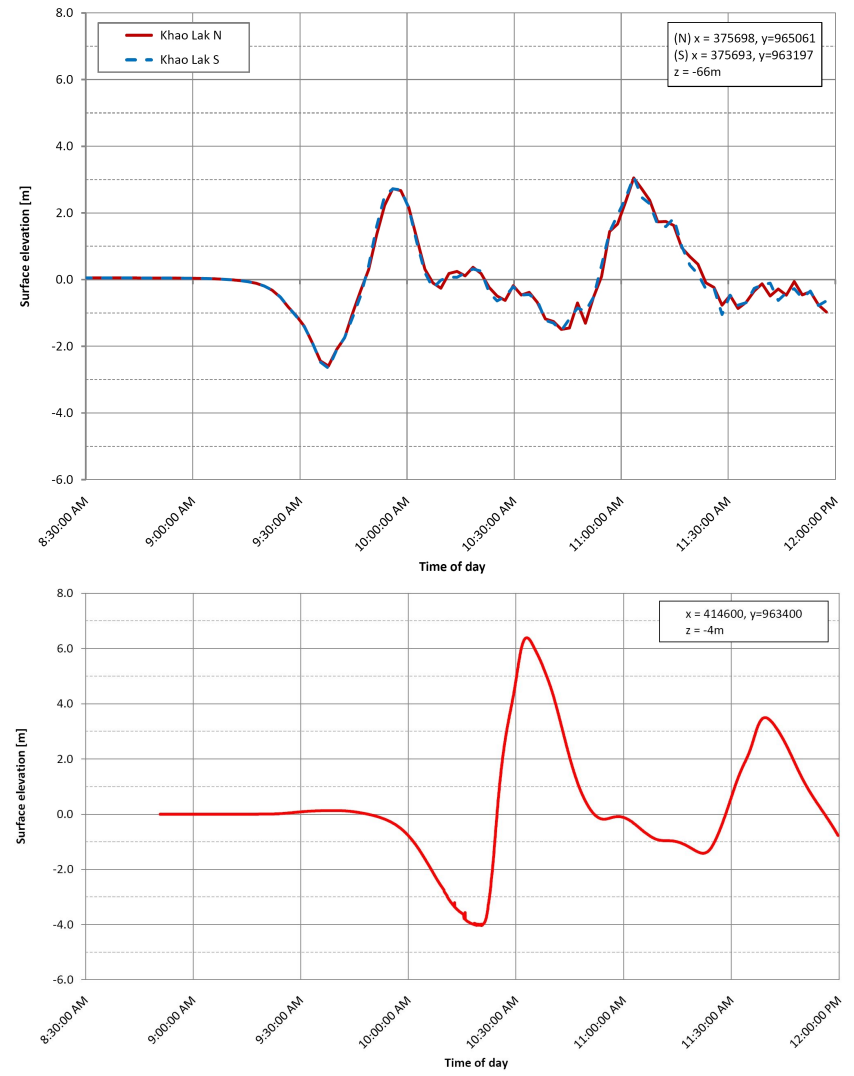

Fig. 4. Time series for the 2004 tsunami at the boundary between ComMIT and Mike modeled with ComMIT (two points connected to a west boundary, top) and time series from Mike 21 FM close to the coast in Ban Niang as an example (bottom).

our case $M=90 \mathrm{~m}^{1 / 3} \mathrm{~s}^{-1}$ provided the best fit in combination with the choice of the other parameters when validating inundation against field observations. It also has to be taken into account that the accuracy of validation depends not only on offshore bottom roughness but also on source parameters or tidal variations, which also come with some uncertainties. Since our focus was the accurate modelling of inundation and we therefore needed a good fit with the observed water levels to draw conclusions on inundation patterns, we have 


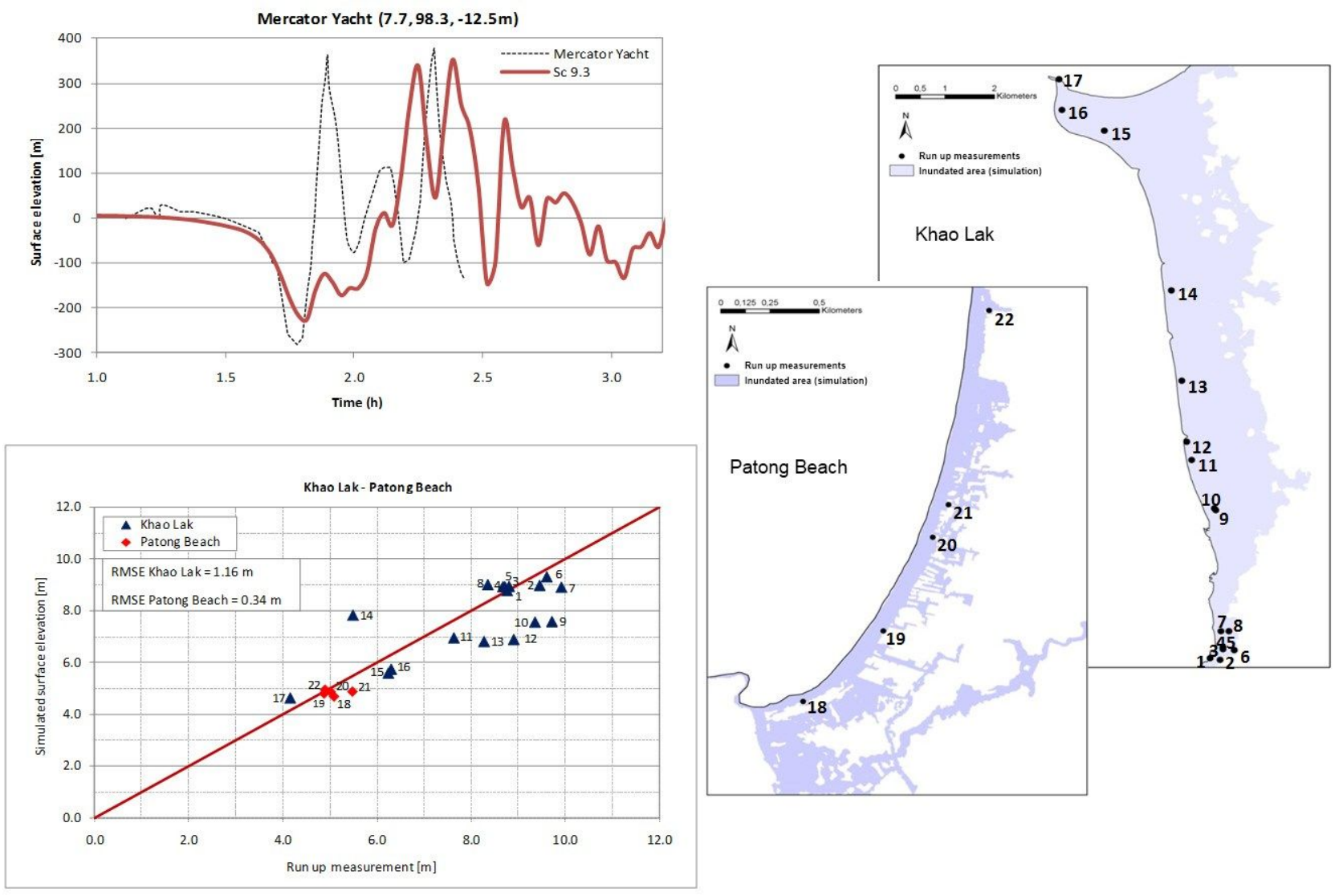

Fig. 5. Comparison of the modeled surface elevation with the echo sounder of the Mercator Yacht (top left) and the measured tsunami run up heights from the Thailand Group (2005).

chosen $M=90 \mathrm{~m}^{1 / 3} \mathrm{~s}^{-1}$ offshore. The west boundary was defined according to the time series from ComMIT (Fig. 4), all other boundary conditions were set to zero normal velocity. These "closed" boundaries have to be considered as potential sources of error as ideally all boundaries should be open. However, varying time series at all boundaries led to numerical instabilities. Analyzing the results the nearboundary zone was not considered. The temporal resolution ranged from $0.01 \mathrm{~s}$ to $1 \mathrm{~s}$. The time step was chosen automatically based on the Courant number. Tides were not considered. The final size of the model grids was: Ban Nam Khem: $68.62 \times 5.51 \mathrm{~km}$, Khao Lak: $41.96 \times 1.86 \mathrm{~km}$, and Patong Beach: $29.03 \times 3.15 \mathrm{~km}$.

\subsection{Validation}

For drawing conclusions on inundation patterns from the 2004 tsunami in the area, the model results had to be validated by comparing them to field observations and measurements. The ComMIT results have been compared to the echo sounder signal of the Mercator Yacht (KNMI web page), which was located near Phuket during the tsunami (Fig. 5). The comparison shows that wave amplitudes are well represented whereas a time shift occurs for the first peak. This might have been influenced by the location of the input time series. The results of the subsequent MIKE 21 FM simulation were validated by comparing the modeled surface elevation with measured water marks in the field. Measurements were taken from the survey of the Thailand Group (2005) and Tsuji et al. (2006). These measurements are tide corrected and correspond to the modeled surface elevation above msl Results show that despite a certain variability of the measured heights occurring when mapping water marks in the field as well as in the numerical simulation itself, the modeled surface elevation fits well showing an RMS error of $0.34 \mathrm{~m}$ in Patong Beach and $1.16 \mathrm{~m}$ in Khao Lak (Fig. 5). The validation was found sufficiently accurate to draw conclusions from the results which will be discussed in the following. It should be considered though, that different combinations of parameters (e.g. higher initial surface elevation together with higher offshore roughness or different onshore roughness) may lead to similarly good validation results but different values for e.g. flow velocities.

The 2004 tsunami simulation is called "M9.3 scenario" hereafter. 

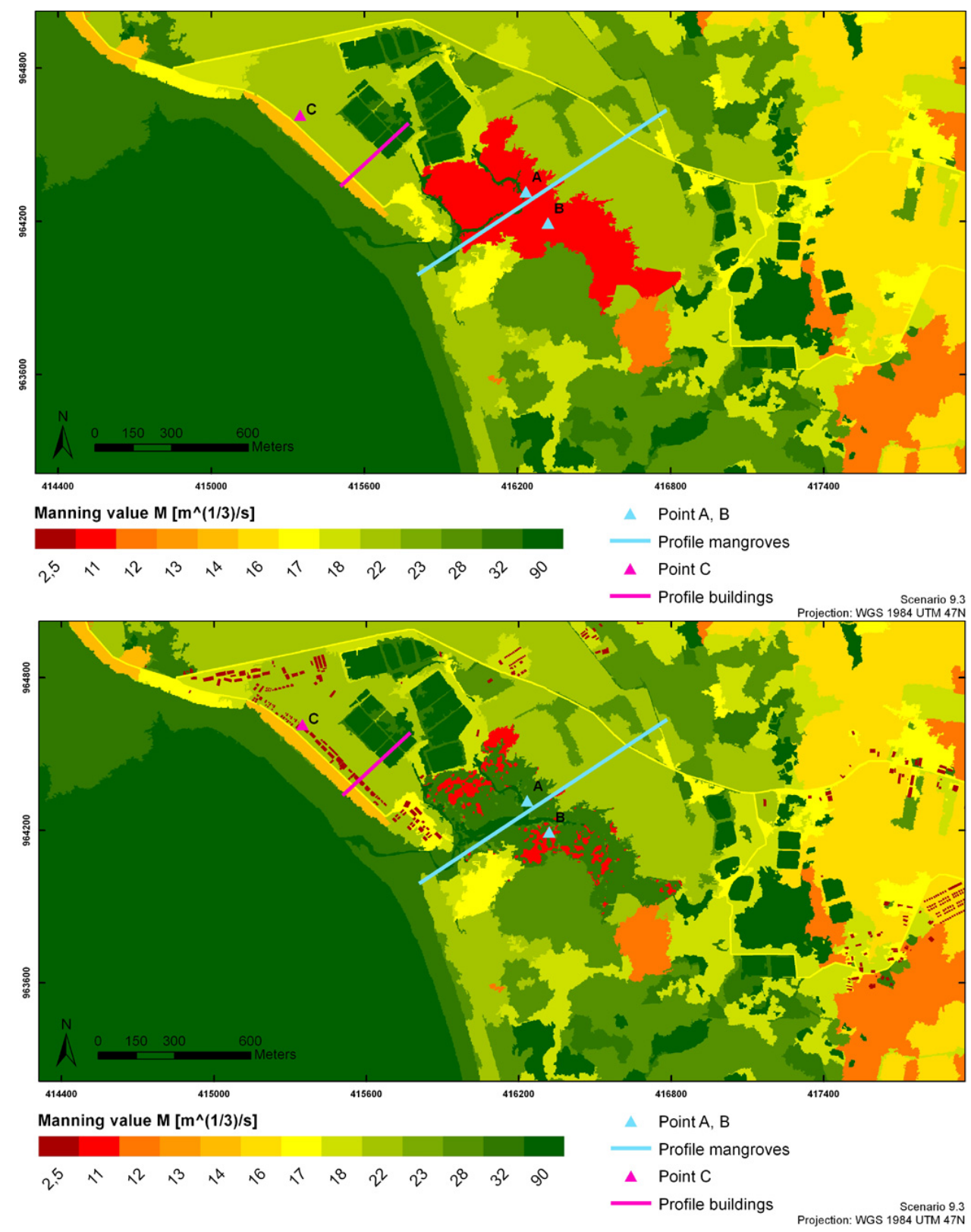

Fig. 6. Roughness maps for the Khao Lak study area with mangroves as from 2003 (top), and without mangroves as from 2005 (bottom). The bottom panel also shows the buildings considered in the analysis.

\section{Results}

The results of inundation modeling were analyzed regarding the influence of land cover roughness and buildings on key parameters of the inundation process such as total water depths $t w d(t)$ (water level above ground), inundation extent, velocities in $\mathrm{x}$-(west-east) direction $u(t)$, current speed as the resulting overall velocity, and flux (flux $(t)=\max (t w d(t) *$ $u(t))$ in west-east direction. West-east direction here corresponds to the onshore-direction. The role of buildings was investigated in both rural and urban areas.

\subsection{Influence of land cover roughness on tsunami inundation}

Since mangroves are assumed to have the most significant influence on wave attenuation, we focused on the aforementioned mangrove area. Based on the pre-(2003) and post(2005) roughness maps (Fig. 6), two simulations were performed. For the pre-tsunami roughness (2003), Manning values for healthy mangroves $\left(M=11 \mathrm{~m}^{1 / 3} \mathrm{~s}^{-1}\right)$ were chosen as measured in the field and calculated using Eq. (1) (Table 1). In the post tsunami situation for the reduced mangrove 


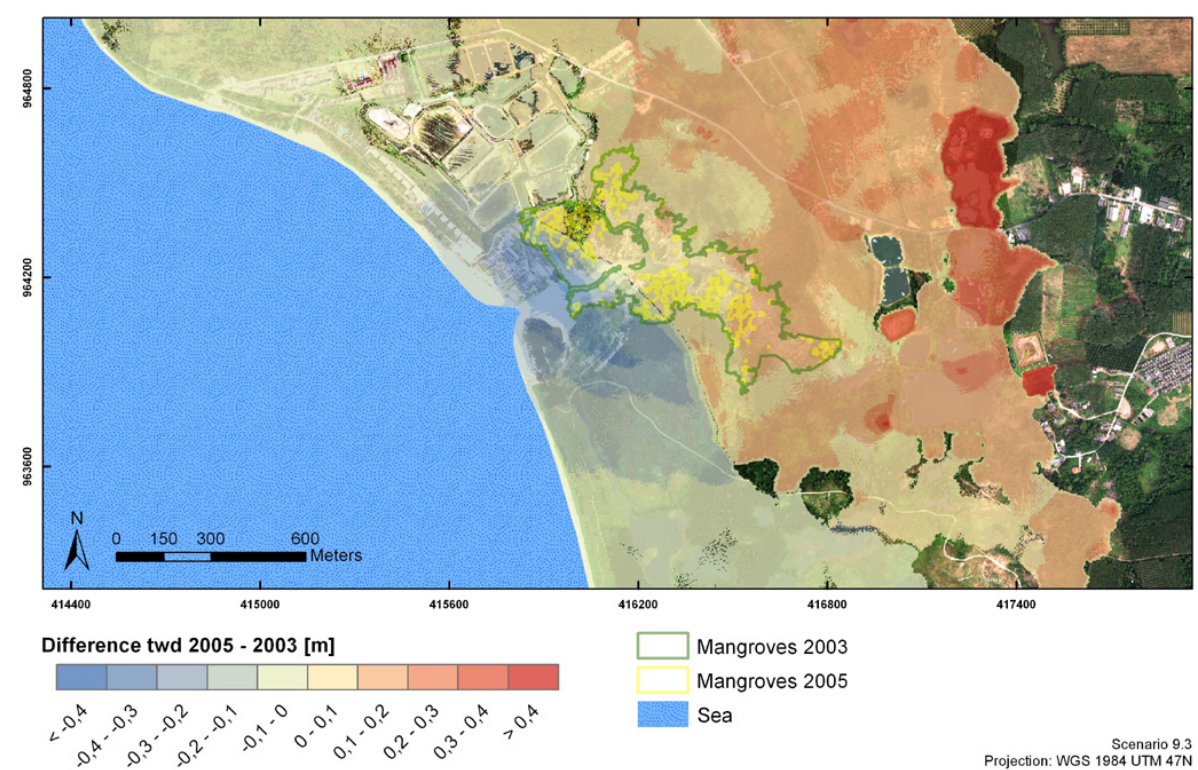

Fig. 7. Differences in total water depths between Sc2005 (without mangroves) and Sc2003 (with mangroves).

patch, Manning values considered the new land cover, which consists mainly of mud/sand and remaining trunks from destroyed mangroves mixed with sparse vegetation. Manning values for the new land cover are given in Table 1.

The two different Mike simulations were compiled using the M9.3 scenario and called hereafter:

1. "Sc2003", pre-tsunami, "with mangroves" and

2. "Sc2005", post-tsunami, "without mangroves".

For both scenarios two points (point A and point B, Fig. 6) and one profile ("profile mangroves", Fig. 6) were analyzed. Point $\mathrm{A}$ is located at an elevation of $0.08 \mathrm{~m}$ above msl in an area which was a mangrove area in Sc2003 and a mud area in Sc2005. Point B is located at $1.45 \mathrm{~m}$ above msl and is located inside the mangroves at both dates. The profile crosses an area covered with mangroves before the tsunami, being without mangroves after the tsunami. Results show that the inundation extent changes only little from 348 ha in Sc2003 to 352 ha in Sc2005. On the contrary, a comparison of the vertical differences of the total water depths shows more significant differences. At each point the relative difference between Sc2005 and Sc2003 was calculated. In Fig. 7 the blue areas indicate areas where the total water depths in Sc2003 are larger than in Sc2005, whereas red areas show the opposite, i.e. total water depths with mangroves (Sc2003) are smaller than without mangroves (Sc2005).

Figure 7 suggests that for Sc2003, the total water depths increase in front of the mangroves and surrounding areas by up to $0.4 \mathrm{~m}$ (from approximately $6.70 \mathrm{~m}$ to $7.10 \mathrm{~m}$ ). In contrary, behind the mangroves the total water depths are reduced by up to $0.65 \mathrm{~m}$ in Sc2003 as compared to Sc2005.

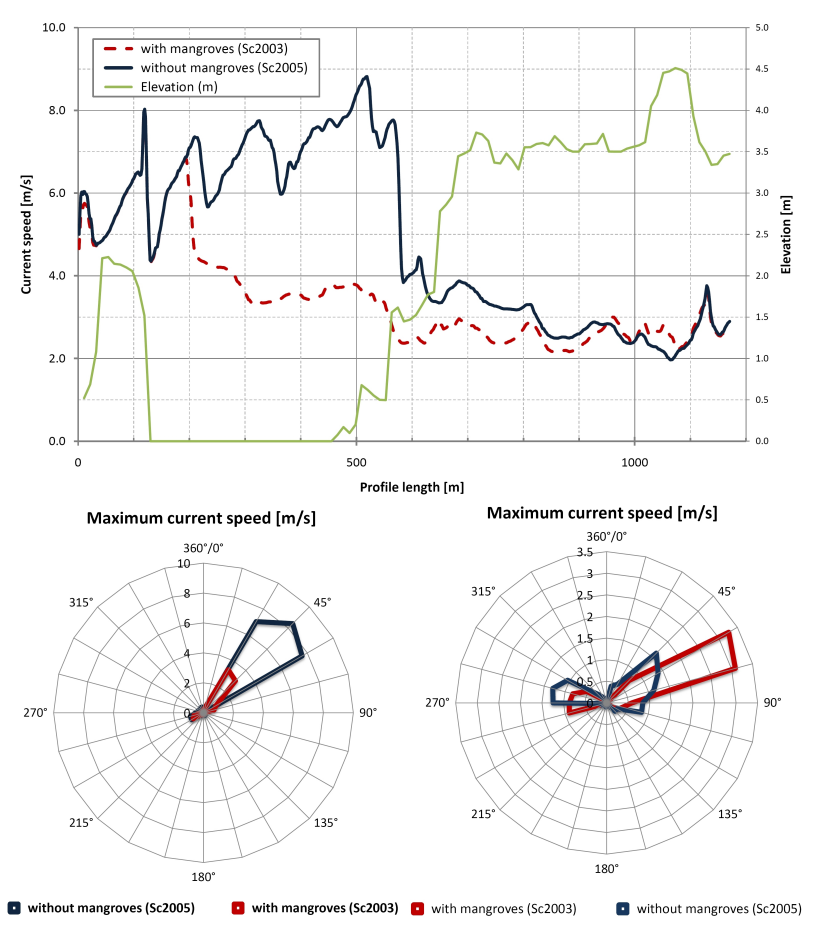

Fig. 8. Current speed "profile mangroves" in Khao Lak for Sc2003 and Sc2005 (top), and for point A (bottom left) and B (bottom right).

This effect increases with distance from the shore suggesting that the mangroves have reduced the total water depths.

With respect to current speed, Fig. 8 plots the current speed as a function of the length of the "mangrove profile" (Fig. 6), starting from zero at sea level and ending at about 

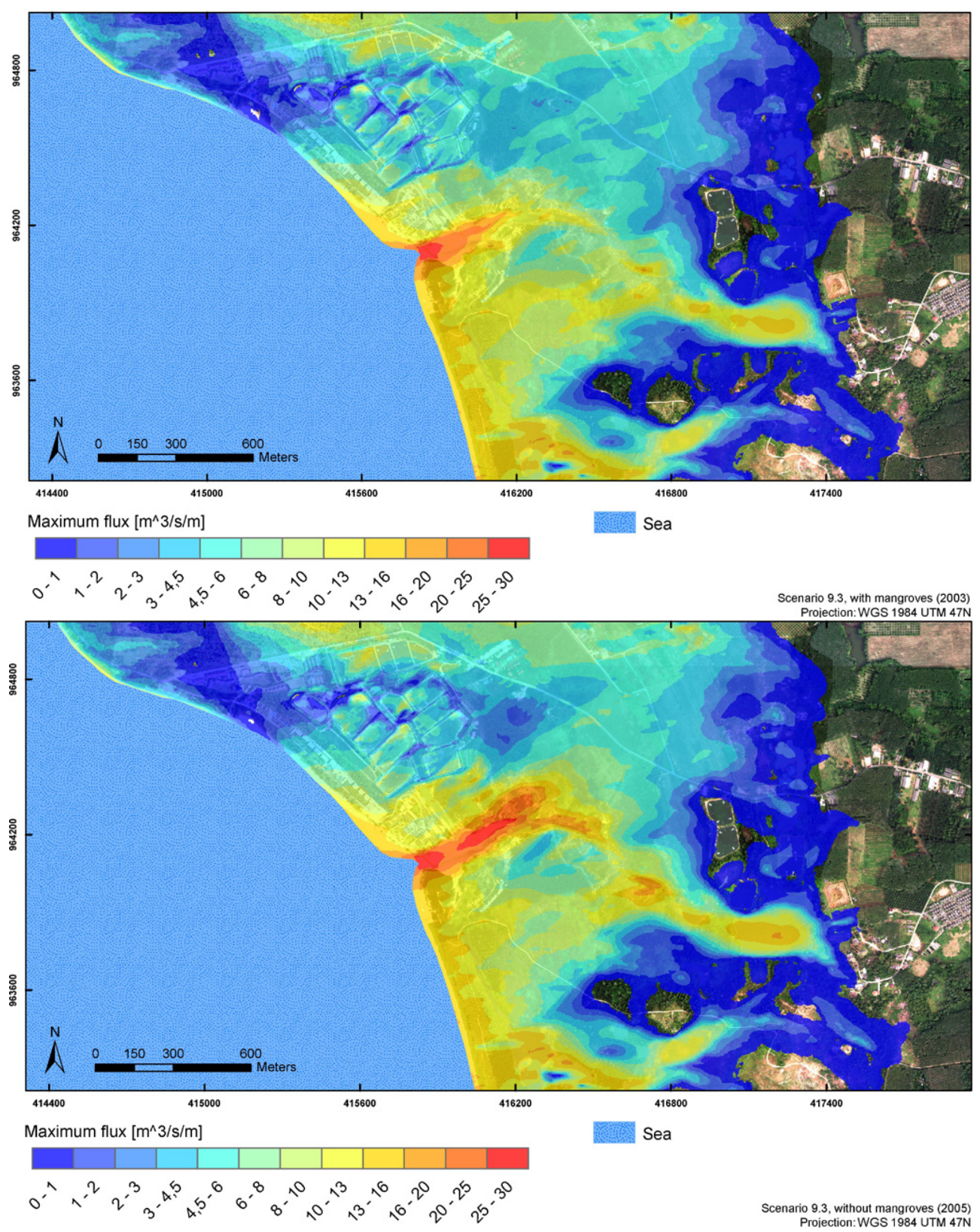

Fig. 9. Maximum flux with mangroves, Sc2003 (top), and without mangroves, Sc2005 (bottom).

$1.2 \mathrm{~km}$ from the sea. The dashed line represents the simulated current speed for Sc2003, the solid line represents Sc2005, and the green line shows the elevation profile. The spider diagram indicates the magnitude of the current speed for Sc2003 and Sc2005, together with the flow direction at Points A and B, respectively. Results for the differences in maximum current speed show that in both scenarios, the simulation is characterized by a short run up identical in both cases. For locations further from the shoreline, velocities decrease slowly again. The Sc2003 line drops from about $7 \mathrm{~m} \mathrm{~s}^{-1}$ to $4 \mathrm{~m} \mathrm{~s}^{-1}$ almost instantly when it hits the mangroves at a length of ca. $200 \mathrm{~m}$ from the coast, which clearly indicates the influence of the vegetation, assuming that a Manning value of $M=11 \mathrm{~m}^{1 / 3} \mathrm{~s}^{-1}$ represents the mangrove forest sufficiently well. In Sc2005 the current speed is almost constant and only drops from $\sim 9 \mathrm{~m} \mathrm{~s}^{-1}$ to $4 \mathrm{~m} \mathrm{~s}^{-1}$ when the elevation increases rapidly to $7.5 \mathrm{~m}$. The decreasing current speed in the mangrove areas also leads to a slight increase of velocities around and behind this area, due to increased flow around the mangroves. At point A (Fig. 6), there is a delay of the tsunami wave of $45 \mathrm{~s}$ in Sc2003 as compared to Sc2005. Moreover, due to the land cover roughness the duration of the run up takes $100 \mathrm{~s}$ longer, whereas the back flow is accelerating in Sc2005. 

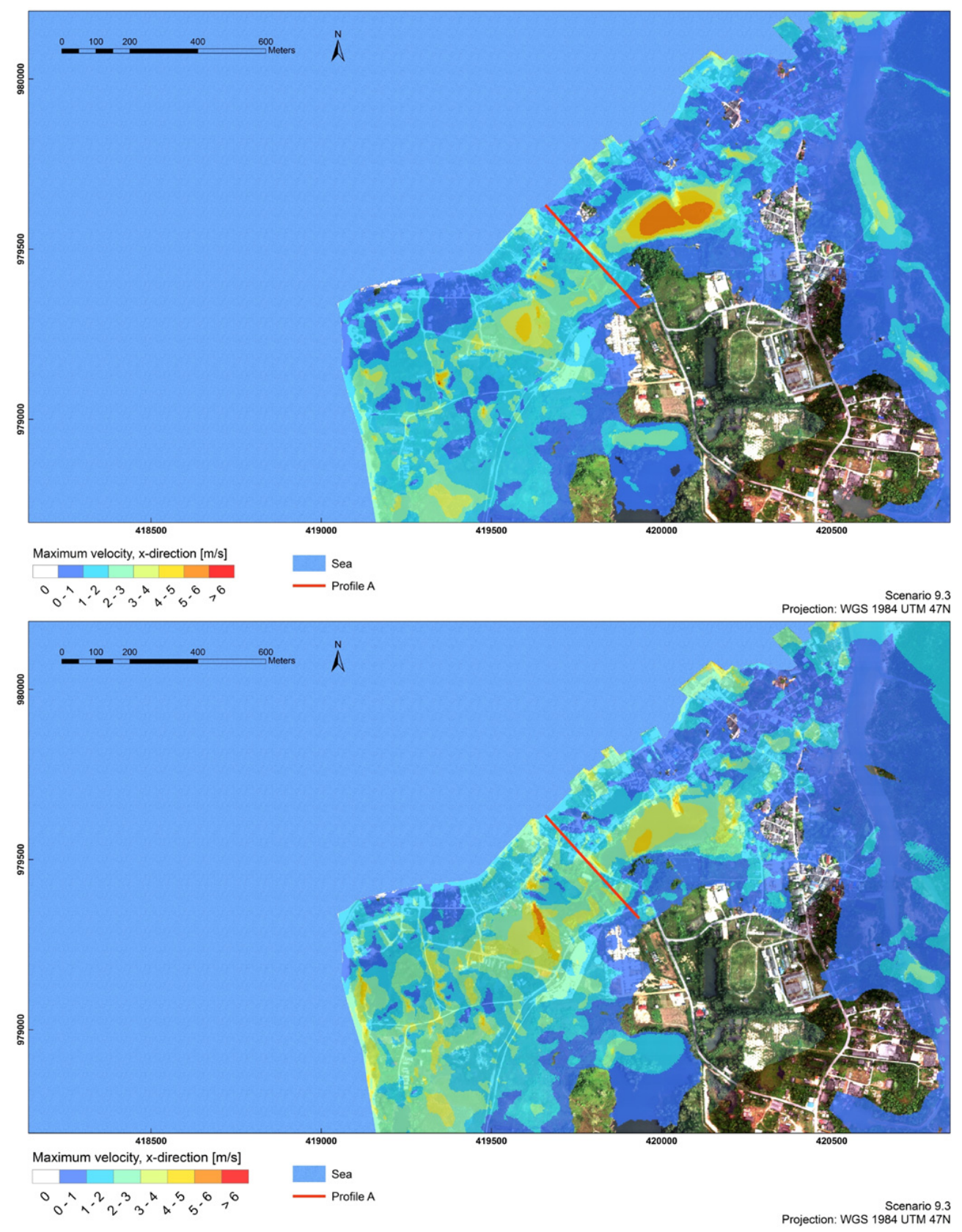

Fig. 10. Influence of building and land cover roughness on flow velocities in x-direction in rural areas. Top: varying Manning values according to land cover (Table 1). Manning values for buildings are $11 \mathrm{~m}^{3} \mathrm{~s}^{-1}$, as houses in Ban Nam Khem are classified as non-resistant. Bottom: constant Manning value $M=32 \mathrm{~m}^{1 / 3} \mathrm{~s}^{-1}$. Note the profile line drawn in red.

Both the total water depth and the velocity are assumed to be the most relevant parameters for causing tsunami-induced damages and were therefore combined to the flux and further analyzed. The highest flux (up to $30 \mathrm{~m}^{3} \mathrm{~s}^{-1} \mathrm{~m}^{-1}$ ) occurs in the tidal inlet (Fig. 9). The mean flux values for both scenarios are relatively close: $5.41 \mathrm{~m}^{3} \mathrm{~s}^{-1} \mathrm{~m}^{-1}$ (Sc2003) and $5.65 \mathrm{~m}^{3} \mathrm{~s}^{-1} \mathrm{~m}^{-1}$ (Sc2005), indicating that the same energy has hit the coast. However, the colors indicate that the distribution of maximum fluxes in the area is very different (from $0-30 \mathrm{~m}^{3} \mathrm{~s}^{-1} \mathrm{~m}^{-1}$, Fig. 9), due to local effects. A high flux can be due to a high total water depth or a high velocity, or both. In the inlet, higher fluxes can be observed in Sc2005 than in Sc2003, together with a much larger distance of high flux values from the coast, suggesting that the mangrove forest in Sc2003 decreased the flux here locally. Overall, in Sc2005 the flux may have become up to $15 \mathrm{~m}^{3} \mathrm{~s}^{-1} \mathrm{~m}^{-1}$ higher than in Sc2003, mainly because of the higher current velocity as described above. At Point $\mathrm{A}$, the flux increased from 10 to $22 \mathrm{~m}^{3} \mathrm{~s}^{-1} \mathrm{~m}^{-1}$. 


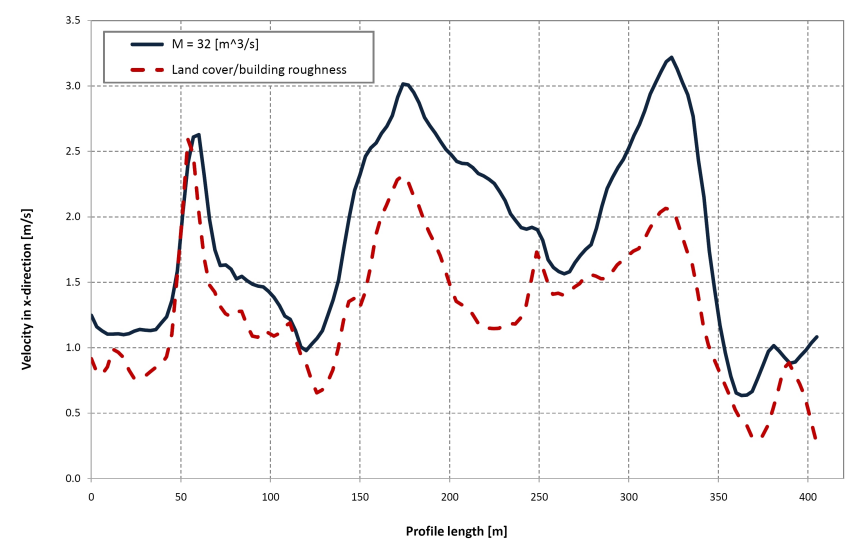

Fig. 11. Maximum flow velocities in $\mathrm{x}$-direction for the profile $\mathrm{A}$ in Fig. 10.

A slightly modified situation arises when there is a variety of land cover classes with different roughness, such as in the example of Ban Nam Khem. Figure 10 shows the results of two numerical simulations where one (top panel) is based on Manning values assigned to the different land cover classes (according to Table 1) in the area and the other (bottom panel) uses a constant Manning value of $M=32 \mathrm{~m}^{1 / 3} \mathrm{~s}^{-1}$.

The results show that flow velocities differ considerably from each other whereas the inundation extent again is about the same. However, differences of the flow velocities are visible from different locations and may be as high as 1 to $2 \mathrm{~m} \mathrm{~s}^{-1}$ in this case.

Flow velocities show a sensitive response to the different roughness in the area (Fig. 11). The lines diverge at $65 \mathrm{~m}$ from the shore when a settlement starts due to the higher roughness assigned to single buildings in the case with varying roughness information (streets were still $M=$ $32 \mathrm{~m}^{1 / 3} \mathrm{~s}^{-1}$ ). The difference increases when it comes to woodland with a homogenous higher roughness value at $300 \mathrm{~m}$ distance from the shore. The increases and decreases in both lines result from differences in elevation over the length of the profile. Velocities increase with decreasing elevation and decrease with rising elevation, whereas the general tendency of the dashed line being lower than the solid line results from the considered land cover roughness. Looking at the spatial distribution of flow velocities in Fig. 10, differences can be seen in increased velocities in ponds and the river or decreased velocities over the settlement in the upper panel. Also, casuarina forests at the spit in the NW show some effects of attenuation.

\subsection{Influence of buildings on tsunami inundation}

To simulate inundation in urban areas so that it fulfills the requirements of an object-oriented damage analysis and local hazard mapping, buildings were considered according to different approaches discussed in the literature. The influence of buildings on inundation patterns has been analyzed for $\mathrm{Pa}-$ tong Beach (resistant buildings, high building density), Khao Lak (few buildings, hotels, larger distance between buildings) and Ban Nam Khem (non-resistant houses, poor quality). Four different scenarios (compare also Gayer et al., 2010; Jakeman et al., 2010; Taubenböck et al., 2009) were simulated to determine the one that fits best with the 2004 event:

a. "Buildings as elevation data": for this purpose the MFC elevation model described in Sect. 3.3, which includes buildings as 3-D objects was used. This approach was only applied in the study area Patong Beach as the effects in Khao Lak and Nam Khem were assumed to be insignificant because many houses collapsed during the 2004 event or houses are sparsely distributed, so that water might flow around the buildings without significant changes in flow dynamics.

b. "Buildings as roughness": buildings were not considered as elevation data (3-D objects) like in the previous approach but were included in the roughness map in Mike 21 with a roughness value of $M=2.5 \mathrm{~m}^{1 / 3} \mathrm{~s}^{-1}$ for single building polygons (according to Gayer et al., 2010), surrounded by cells with $M=32 \mathrm{~m}^{1 / 3} \mathrm{~s}^{-1}$ for streets.

c. "No buildings, urban area roughness": buildings were not considered at all. Instead, a homogenous Manning value $M=12.5 \mathrm{~m}^{1 / 3} \mathrm{~s}^{-1}$ representing dense urban areas (Table 1) was assigned to the whole city of Patong Beach.

d. "No buildings": buildings were not considered at all and only the bare ground elevation model was used. A homogenous Manning value $M=32 \mathrm{~m}^{1 / 3} \mathrm{~s}^{-1}$ was assigned to the whole city of Patong Beach.

A long shore profile (Fig. 12) has been analyzed in more detail for the four scenarios in Patong Beach.

The inundation extent for the $M 9.3$ scenario varies significantly for the aforementioned approaches (a), (b), (c) and (d) with buildings as elevation data, buildings as roughness, urban area roughness, and no buildings (Fig. 13). The inundated area for the scenario including buildings as elevation data is 78 ha, for the urban are roughness 92 ha $(+18 \%)$, with buildings as roughness it is 106 ha $(+36 \%)$, and 133 ha $(+71 \%)$ with no buildings. The results have been checked against measured water marks from the 2004 tsunami (Fig. 5) where it was found that the "buildings as elevation data" approach matches the observed situation best. However, it has to be taken into account that in a real case, water is not entirely flowing around the houses or reflected, but may also flow into the buildings. Validation of the simulation with buildings as roughness provided very similar results to those with buildings as elevation data. 

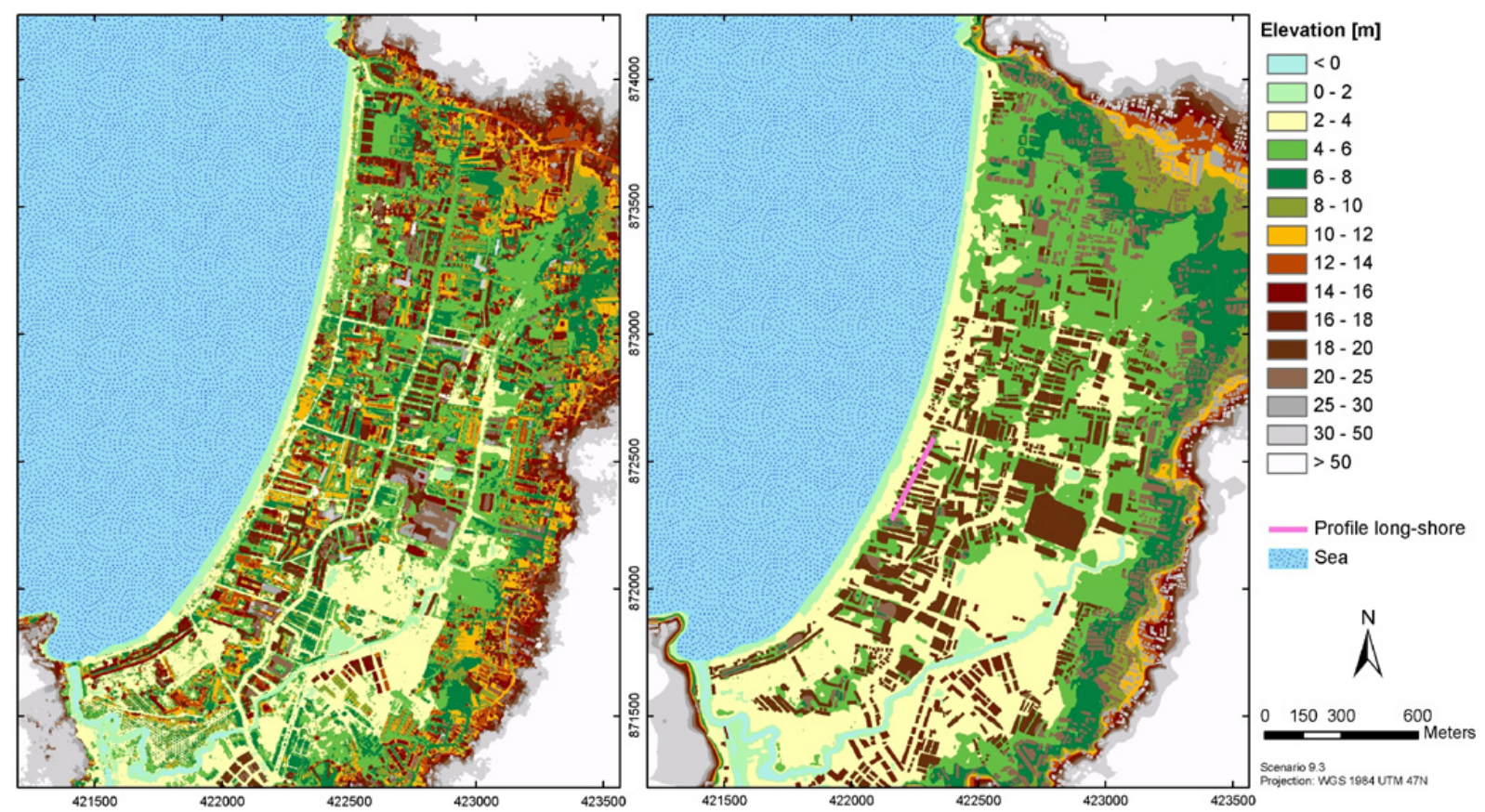

Fig. 12. The original MFC DSM for Patong Beach (left) and the corrected elevation model after removing vegetation and buildings and including the 3-D building layer (right). The right panel shows the profile for the analysis of inundation parameters in Patong Beach.

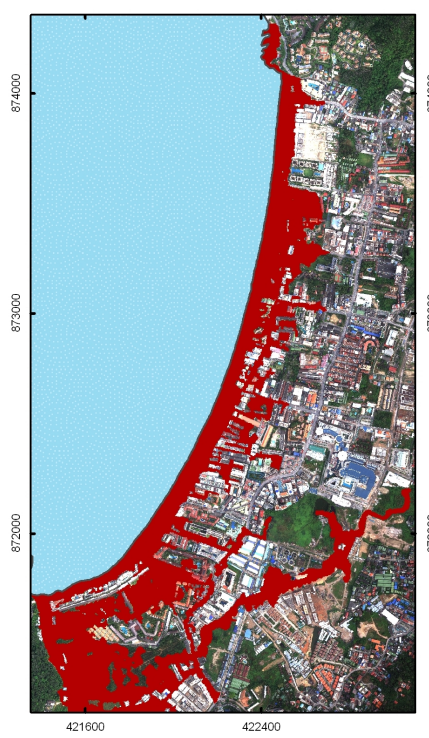

$\Lambda^{N}$

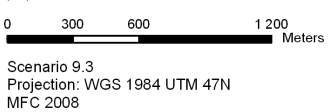

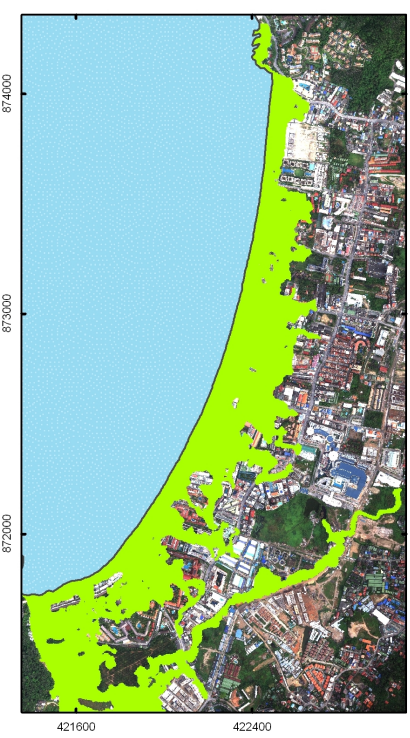

422400

Inundation extent

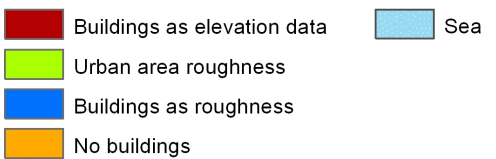

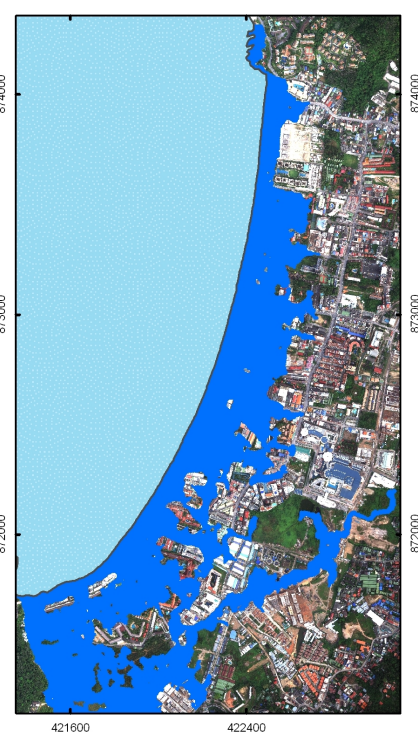

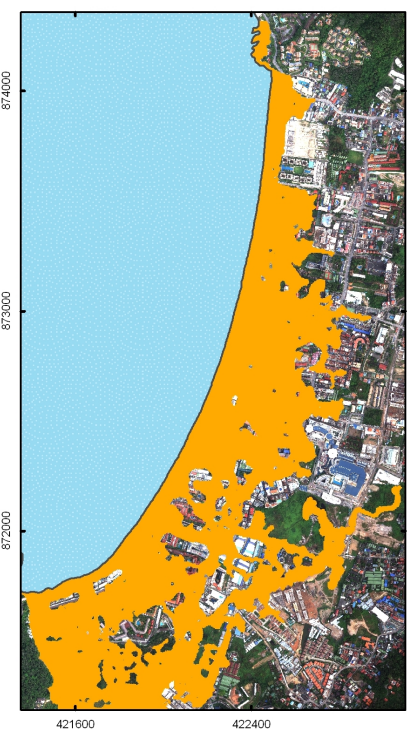

422400

Fig. 13. Inundation extent in Patong Beach for the $M 9.3$ scenario using four different approaches to implement buildings: buildings as elevation data, urban area roughness $\left(M=12.5 \mathrm{~m}^{1 / 3} \mathrm{~s}^{-1}\right)$, buildings as roughness $\left(M=2.5 \mathrm{~m}^{1 / 3} \mathrm{~s}^{-1}\right)$, and no buildings $\left(M=32 \mathrm{~m}^{1 / 3} \mathrm{~s}^{-1}\right)$. 

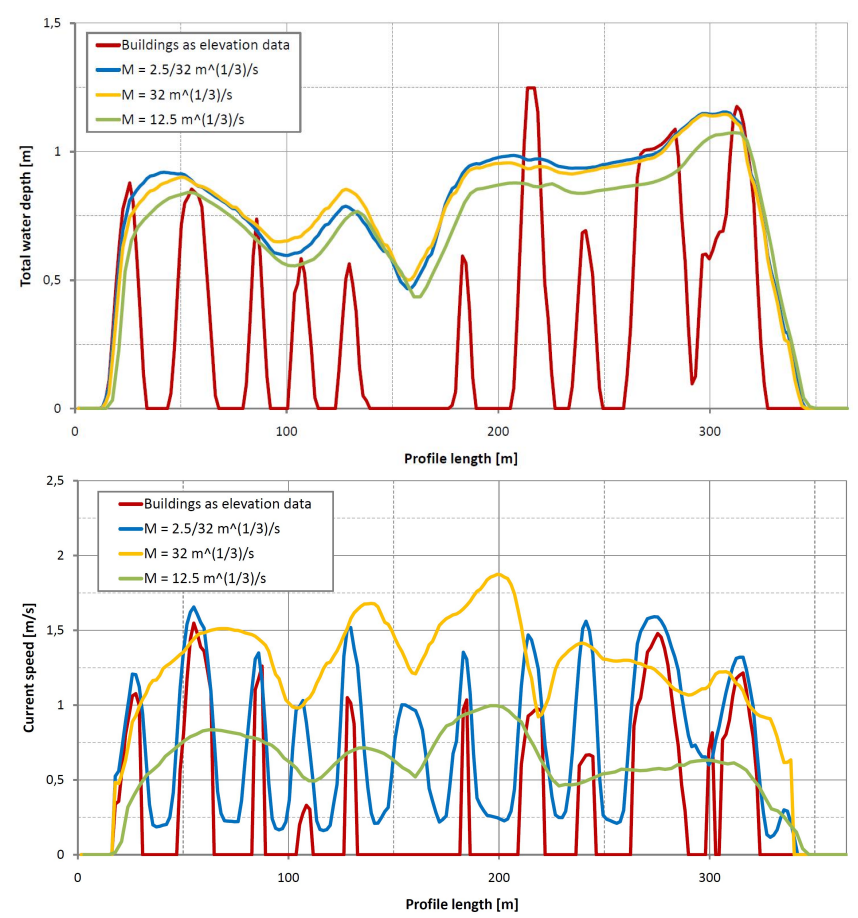

Fig. 14. Long-shore profile in Patong Beach: total water depth (top) and current speed (bottom) for buildings as elevation data; buildings as roughness: $M=2.5 \mathrm{~m}^{1 / 3} \mathrm{~s}^{-1}$; urban area roughness: $M=12.5 \mathrm{~m}^{1 / 3} \mathrm{~s}^{-1}$; and $M=32 \mathrm{~m}^{1 / 3} \mathrm{~s}^{-1}$ uniform values.

The mean values of the total water depth vary from $1.43 \mathrm{~m}$ for "buildings as elevation data", $1.22 \mathrm{~m}$ for buildings as roughness $(-15 \%)$, and $1.09 \mathrm{~m}$ without buildings $(-24 \%)$. A local analysis shows a setup of water in front of the buildings close to the beach. In the dataset with buildings included in the elevation model, buildings act as walls, directly reflecting the water. Therefore, less water is flowing into the city and the maximum inundation extent is closer to the beach. The mean water depth, however, has to be only taken as an indicator since local variations of this parameter can vary significantly depending on the local topography and building situation.

In Fig. 14, the total water depth and the current speed are shown for the long-shore profile indicated in Fig. 12. In each of the figures, the four approaches for the consideration of buildings (a), (b), (c), (d) are represented by a colored line (red $=$ buildings as elevation data; blue $=$ buildings as roughness, $M=2.5 \mathrm{~m}^{1 / 3} \mathrm{~s}^{-1}$; green = urban area, $M=$ $12.5 \mathrm{~m}^{1 / 3} \mathrm{~s}^{-1}$; yellow $=$ no buildings, $M=32 \mathrm{~m}^{1 / 3} \mathrm{~s}^{-1}$ ). The profiles suggest that the total water depth does not differ significantly between buildings as elevation data or the roughness approaches. It is however slightly lower in the case of buildings as elevation data. This might be due to the reflection of water at the first buildings at the beach. Areas where buildings are located are, of course, flooded in the cases with no elevation data for buildings. More significant differences can be observed for the current speed. For the buildings with high roughness, current speeds are very similar to the situation with buildings as elevation data, as velocities decelerate significantly (up to about $85 \%$ ) over the building polygons with $M=2.5 \mathrm{~m}^{1 / 3} \mathrm{~s}^{-1}$. Channel effects and increasing velocities in the streets can also be visualized. With no buildings and constant Manning values of $M=32 \mathrm{~m}^{1 / 3} \mathrm{~s}^{-1}$, current speeds are more homogenous since the influence of streets is not considered. Assuming a homogenous high roughness of $M=12.5 \mathrm{~m}^{1 / 3} \mathrm{~s}^{-1}$ for the whole urban area leads to significantly lower current speeds compared to the $M=32 \mathrm{~m}^{1 / 3} \mathrm{~s}^{-1}$ case in the entire profile, indicating that the flow velocities are reduced too much in comparison to the other results.

The four approaches (a, b, c, d) have further been analyzed according to differences in fluxes (Fig. 15).

From the top two panels it can be noted that there is a high difference between the flux in the streets and the areas where buildings are located ("stripes"). This suggests that streets and buildings can also be represented using very high roughness values for buildings. Both approaches result in similar fluxes, except that the inundation extent is higher in the case where buildings are replaced by very high Manning values. In the lower two panels of Fig. 15, this stripe-wise representation of streets is no longer visible and the whole area is more or less flooded homogenously. Hence, results for local current speed, water depths, and the overall inundation extent are very different as compared to the first cases.

The analysis in a dense urban area with resistant and high buildings, suggests that including buildings as elevation data provides the best results according to the modeled surface elevation in the validation points (Fig. 5), which is in agreement with results from Jakeman et al. (2010) and Schlurmann et al. (2011). However, the approach, to assign very high Manning values $\left(M=2.5 \mathrm{~m}^{1 / 3} \mathrm{~s}^{-1}\right)$ to resistant buildings as proposed by Gayer et al. (2010) and Leschka et al. (2009), provides similar results in the validation points, and for flux and current speeds (Figs. 14 and 15). In this case, the water will flow over buildings in the simulation, but the channel effect is also well represented (Fig. 15). It has to be taken into account, though, that the validation points are very close to the shore. A remarkable difference could be observed in the inundation extent between both approaches (Fig. 13). Regarding the fact, that high-resolution surface models, which represent every single building (requiring a resolution of approximately $3 \mathrm{~m}$ ) are seldom available, the roughness approach might be more applicable, although this approach requires at least the geometry of buildings (or blocks) and surrounding streets.

In the rural areas of Khao Lak and Nam Khem, buildings were not included in the elevation model as they are assumed to be non-resistant and to collapse. Nevertheless, as even collapsed buildings might induce bottom roughness, the buildings here are considered using a Manning value of $M=11 \mathrm{~m}^{1 / 3} \mathrm{~s}^{-1}$ (according to Gayer et al., 2010; Leschka et al., 2009). In Fig. 16, the maximum flux is shown for 

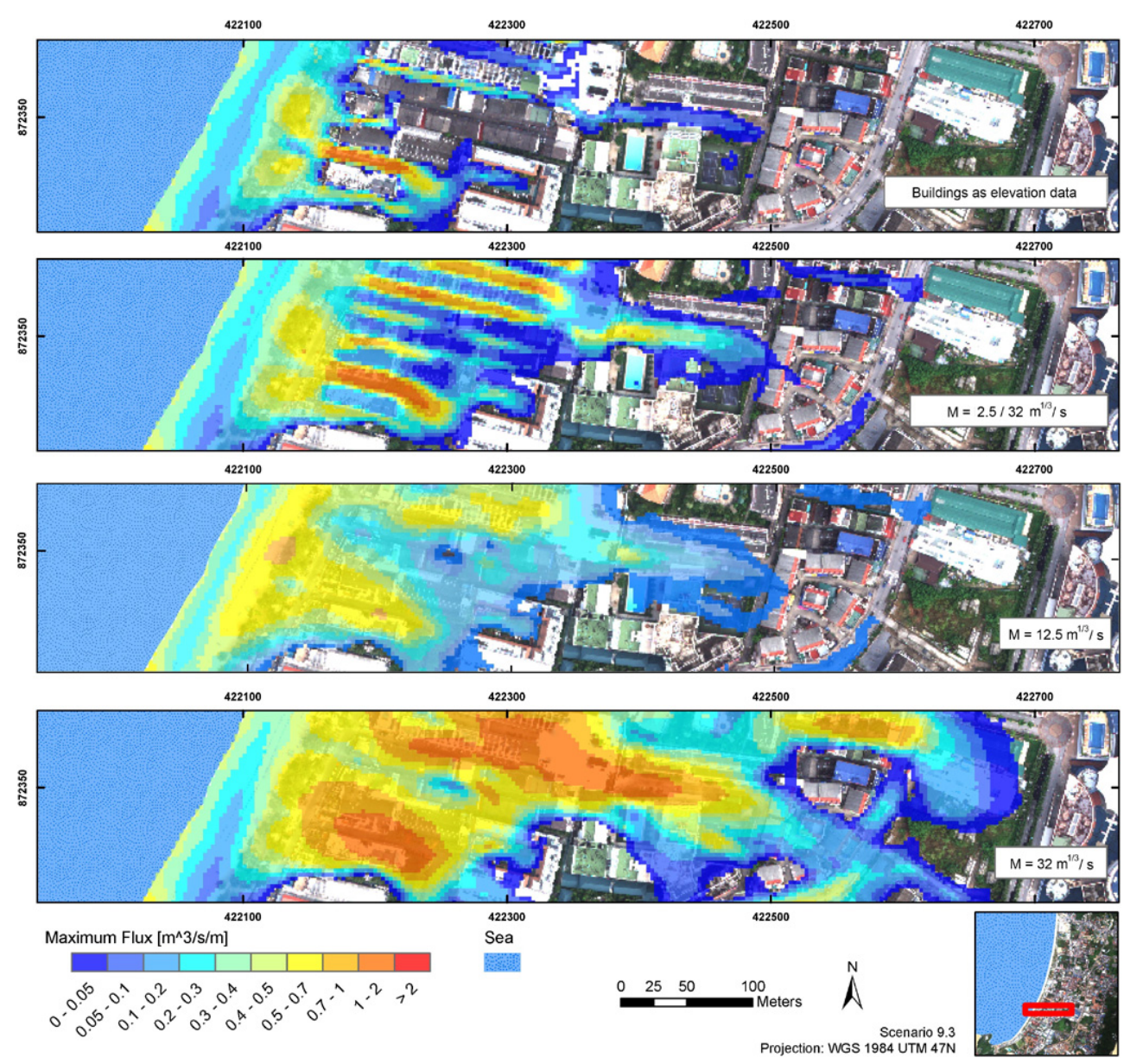

Fig. 15. Maximum flux in Patong Beach, including four different scenarios to represent buildings (top to bottom: buildings as elevation data; $M=2.5 \mathrm{~m}^{1 / 3} \mathrm{~s}^{-1}$; urban area roughness: $M=12.5 \mathrm{~m}^{1 / 3} \mathrm{~s}^{-1}$; and $M=32 \mathrm{~m}^{1 / 3} \mathrm{~s}^{-1}$ uniform values.

the profile "buildings" (Fig. 6) for Khao Lak (top) where differences in flux from building interactions can be identified. The flux increases between buildings represented by high roughness values as a channel effect occurs between the buildings. This effect disappears, when the housing ends. Figure 16 also shows total water depths and current speed in point C (Fig. 6) as a function of time. It can be seen that high roughness values for buildings may also create higher current speed at some places than for cases with no buildings, depending on the location of where these values were observed and whether these specific locations were influenced by the properties of neighboring elements (e.g. when a flow is distributed over a large area it will have a lower velocity than the flow in narrow streets).

\section{Discussion}

In this work, Manning values for different land cover classes have been calculated from field measurements at the Andaman Sea coast of Thailand. Based on these, high-resolution tsunami inundation simulations were performed using three local case studies as an example. The purpose was to quantify the effects of spatial-explicit land cover roughness on inundation simulations and to consider the role of buildings in these simulations, which is relevant for local tsunami damage analysis, risk assessment and management.

The results showed that first of all, topography is the most critical factor as inundation patterns are very sensitive to small changes in topography, provided only by highresolution elevation data. Besides the resolution, the surface character of remote sensing-based elevation data sets needs to be considered, as it may cause considerable offsets in densely vegetated and urban areas. Moreover, a significant influence of land cover roughness could be observed. Mangroves (represented by $M=11 \mathrm{~m}^{1 / 3} \mathrm{~s}^{-1}$ ), for example, have been shown to influence inundation patterns, suggesting that current speeds may be reduced by up to $50 \%$ whereas the maximum inundation extent is similar in the case of simulations with and without mangroves. In a dense urban area, our case study showed that ideally, inundation mapping on 

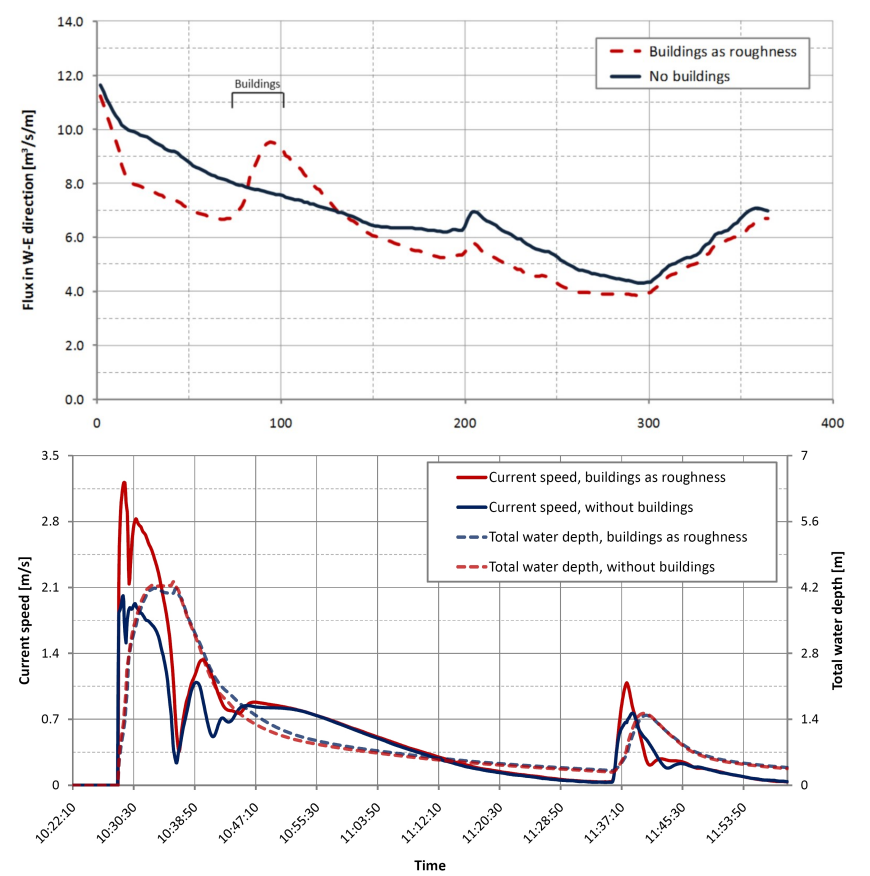

Fig. 16. Top panel: flux between buildings (profile buildings, Fig. 6); bottom: current speed and total water depths with and without buildings as roughness (point $\mathrm{C}$, Fig. 6).

a local scale should include buildings as elevation data or as high roughness polygons with high geometric accuracy (similar results have been obtained by Gayer et al., 2010; Jakeman et al., 2010; Schlurmann et al., 2011; Taubenböck et al., 2009). Using the "bare" elevation with a constant Manning of $M=32 \mathrm{~m}^{1 / 3} \mathrm{~s}^{-1}$ led to a significant overestimation of the inundation extent in our study. Including buildings as elevation data in the model shows $36 \%$ reduction in inundation extent compared to the buildings as roughness in the case of Patong Beach with higher and densely located houses and only small differences (10\% of the area) for less densely distributed or non-resistant houses, such as in the case of Ban Nam Khem or Khao Lak. These results suggest the use of high- resolution elevation data for urban areas with solid and densely located buildings. If the elevation of houses is not available, high roughness values for buildings may be used for modeling an inundation process where water flow is attenuated indirectly with surrounding roughness (e.g. streets) of $M=32 \mathrm{~m}^{1 / 3} \mathrm{~s}^{-1}$, or even lower as suggested by Leschka et al. (2009). Generally, it can be concluded that if highresolution data on land cover or buildings are not available, inundation maps can be expected to be less accurate with respect to inundation depths and only rather crude values for current velocities. In rural areas with low housing densities, however, our study showed that less accurate data can be sufficient to represent the inundation extent.

During this study some limitations, restrictions and further research demands became obvious. For example, the collapse of buildings and trees during the simulation could not be considered. It has been assumed that they withstand the tsunami waves so that dynamic roughness, changing over time during the inundation process, has been ignored (compare also Gayer et al., 2010). It should be noted that flow velocities and total water depths might be altered if the damage effect of the tsunami during the simulation is taken into account as already discussed by Yanagisawa et al. (2009). Although vegetation could be reasonably well represented by Manning values, details of vegetation patterns and their influence on the roughness still need to be further improved, as e.g. the age of vegetation, breaking of trunks, the influence of debris on stability of vegetation, etc. Moreover, Manning values differ in the literature and also deviate partly from findings in this paper. Suppasri et al. (2011), for example, calculated similar roughness coefficients for the built environment but used slightly lower values $(n=0.03)$ for vegetation. Leschka et al. (2009) used higher values for mangroves $(n=0.13)$ and slightly lower ones $(n=0.032)$ for plantations in Indonesia. There might be several reasons for these differences, such as the local variation of the composition of vegetation types, different equations to calculate Manning values and partly different parameters in these equations. The mechanisms of tsunami attenuation by coastal vegetation and the governing parameters are still not fully understood (Strusińska et al., 2010). Further research on this might lead to improved roughness coefficients and thus to decreased uncertainties in numerical inundation simulations.

Flotsam, which can substantially contribute to damage and destruction (Bernard et al., 2006; Dalrymple et al., 2006) has also not been considered in the model. Many videos taken in Patong Beach and Khao Lak showed that waves transporting cars, trees, or material from destroyed houses, moved through the streets causing further damage and contributing significantly to the loss of life. Thus, if detailed quantification of loss of life or damages is the purpose, flotsam should be considered. The numerical models used in this study did also not simulate sediment transport and/or morphodynamic changes. It is, however, known that large amounts of sand were transported. This may have had an influence on inundation and on the damages to buildings and assets in the street as well as vegetation in the area. Local morphological changes are also expected to show influence on the hydrodynamics of the waves and the backflow of water.

The availability of reliable validation points is an issue when numerical results are compared to these data. Uncertainties in these comparisons do not only stem from the numerical results but also from the accuracy of field measurements after the tsunami. Tidal influence, reference levels, potential changes in the area after the impact, accuracy of the GPS measurements, and so forth have to be taken into account. However, the more reliable data (e.g. by better techniques) that can be collected, the better and easier the calibration of complex numerical models will be. 
In conclusion, in this case study an approach has been presented of how to produce spatially and temporally detailed information on inundation characteristics by taking land cover roughness into account. Since carefully selected, high quality data were available in this study, results have shown good agreement with field observations from the 2004 tsunami. The field data and modeling results obtained here provide another contribution to many of the ongoing tsunami risk studies and are considered to be useful for future scenario-based approaches and local inundation simulations in other areas potentially threatened by tsunamis.

It is believed here that detailed hazard maps may be used to support tsunami risk mitigation in the study areas. Measures for which detailed inundation characteristics might be important are, e.g. the setup of evacuation routes, easy-toreach vertical escape structures, improved land use planning and sustainable coastal management (e.g. regarding green belts), or improved planning of infrastructure.

Eventually spatial information on water depths and flow velocities will allow for ex post and ex ante tsunami damage analyses in the framework of a vulnerability assessment performed in TRAIT.

Acknowledgements. The work presented in this paper was conducted in the project "Tsunami Risks, Vulnerability and Resilience in the Phang-Nga Province, Thailand (TRAIT)" which is funded by the German Research Foundation (DFG) in the framework of a bilateral German-Thai research cooperation. The authors would like to thank the START RC, Chulalongkorn University, Bangkok for providing the sea bottom bathymetry along the west coast of Thailand, the Remote Sensing Solutions GmbH (RSS) and the German Aerospace Center (DLR) for conducting the flight campaign and processing the MFC RGB and elevation data, D. Arp for conducting an extensive field survey to parameterize coastal forests in the study areas as well as H. Bungum, C. B. Harbitz and S. Glimsdal for their contributions to the modeling of the applied earthquake source. The authors also gratefully acknowledge the support of the International Centre for Geohazards (ICG) and the Norwegian Geotechnical Institute (NGI) in writing the present paper.

Edited by: H. Sterr

Reviewed by: B. G. McAdoo and D. Vatvani

\section{References}

Arcement, G. J. and Schneider, V. R.: Guide for Selecting Manning's Roughness Coefficients for Natural Channels and Flood Plains, US Geological Survey Water Supply Paper 2339, 67 pp., 1989.

Arp, D.: Estimating hydrological roughness in coastal habitats - a case study at the Andaman coast of Thailand, unpublishd thesis, Christian-Albrechts Universität zu Kiel, 2009.

Baatz, M. and Schäpe, A.: Multiresolution Segmentation: An optimization approach for high quality multi-scale image segementation, in: Angewandte Geographische Inforamtionsverarbeitung
XII, edited by: Strobl, J., Blaschke, T., and Griesebner, G., Wichmann-Verlag, Heidelberg, 12-23, 2000.

Bernard, E. N., Mofjeld, H. O., Titov, V., Synolakis, C. E., and González, F. I.: Tsunami: scientific frontiers, mitigation, forecasting and policy implications, Phil. Trans. R. Soc. A, 364, 1989-2007, doi:10./1098/rsta.2006.1809, 2006.

Borrero, J. C., Sieh, K., Chlieh, M., and Synolakis, C. E.: Tsunami inundation modeling for western Sumatra, Proc. Nat. Ac. Sci., 103(52), 19673-19677, 2006.

Cochard, R., Ranamukhaarachchi, S. L., Shivakoti, G. P., Shipin, O. V., Edwards, P. J., and Seeland, K. T.: The 2004 tsunami in Aceh and Southern Thailand: A review on coastal ecosystems, wave hazards and vulnerability, Perspect. Plant Ecol., 10, 3-40, 2008.

Dahdouh-Guebas, F., Jayatissa, L. P., Di Nitto, D., Bosire, J. O., Lo Seen, D., and Koedam, N.: How effective were mangroves as a defence against the recent tsunami, Curr. Biol., 15, 443-447, 2005.

Dalrymple, R. A., Grilli, S. T., and Kirby, J. T.: Tsunamis and challenges for accurate modeling, Advances in Computational Oceanography, 19(1), 142-151, 2006.

Danielsen, F., Sørensen, M. K., Olwig, M. F., Selvam, V., Parish, F., Burgess, N. D., Hiraishi, T., Karunagaran, V. M., Rasmussen, M. S., Hansen, L. B., Quarto, A., and Suryadiputra, N.: The Asian Tsunami: A Protective Role for Coastal Vegetation, Science, 310, p. 643, 2005.

Dao, M. H. and Tkalich, P.: Tsunami propagation modelling a sensitivity study, Nat. Hazards Earth Syst. Sci., 7, 741-754, doi:10.5194/nhess-7-741-2007, 2007.

Definiens: Definiens Developer 7.0 Reference Book, Definiens AG, München, 2007.

DHI: MIKE $21 \&$ MIKE 3 FLOW MODEL FM, Hydrodynamic and Transport Module, Scientific Documentation, 2009.

EM-DAT - The International Disaster Database: Centre for Research on the Epidemiology of Disasters, available at: http:/www.emdat.be, (last access: 10 August 2011), 2010.

Gayer, G., Leschka, S., Nöhren, I., Larsen, O., and Günther, H.: Tsunami inundation modelling based on detailed roughness maps of densely populated areas, Nat. Hazards Earth Syst. Sci., 10, 1679-1687, doi:10.5194/nhess-10-1679-2010, 2010.

Goseberg, N. and Schlurmann, T.: Relevant factors on the extent of inundation based on tsunami scenarios for the city of Padang, West Sumatra, in: Proc. International Conference on Tsunami Warning (ICTW) Bali, Indonesia, 12-14 November, 2008.

Goto, K., Chavanich, S. A., Imamura, F., Kunthasap, P., Matsui, T., Minoura, K., Sugaware, D., and Yanagisawa, H.: Distribution, origin and transport process of boulders deposited by the 2004 Indian Ocean tsunami at Pakarang Cape, Thailand, Sediment. Geol., 202, 821-837, 2007.

Grilli, S. T., Ioualalen, M., Asavanant, J., Shi, F., Kirby, J. T., and Watts, P.: Source constraints and model simulation of the December 26, 2004 Indian Ocean tsunami, J. Waterw. Port Coast Ocean Eng., 133, 414-428, 2007.

Imamura, F.: Tsunami modeling: Calculating inundation and making hazard map, in: The Sea, edited by: Robinson, A. R. and Bernard, E. N., Harvard University Press, Cambridge, 15, 321332, 2009.

Ioualalen, M., Asavanant, J., Kaewbanjak, N., Grilli, S. T., Kirby, J. T., and Watts, P.: Modeling the 26 December 2004 Indian Ocean tsunami: Case study of impact in Thailand, J. Geophys. Res., 
112, C07024, doi:10.1029/2006JC003850, 2007.

Jakeman, J. D., Bartzis, N., Nielsen, O., and Roberts, S.: Inundation Modelling of the December 2004 Indian Ocean Tsunami, in MODSIM 2007 International Congress on Modelling and Simulation, in: Modelling and Simulation Society of Australia and New Zealand, edited by: Oxley, L. and Kulasiri, D., 74-80, 2007.

Jakeman, J. D., Nielsen, O. M., van Putten, K., Mleczko, R., Burbidge, D., and Horspool, N.: Towards spatially distributed quantitative assessment of tsunami inundation models, Ocean Dynam., 60(5), 1115-1138, doi:10.1007/s10236-010-0312-4, 2010.

Kathiresan, K. and Rajendran, N.: Coastal mangrove forests mitigated tsunami, Estuarine, Coast. Shelf Sci., 65, 601-606, 2005.

Kawata, Y., Tsuji, Y., Sugimoto, Y., Hayashi, H., Matsutomi, H., Okamura, Y., Hayashi, I., Kayane, H., Tanioka, Y., Fujima, K., Imamura, F., Matsuyama, M., Takahashi, T., Maki, N., and Koshimura, S.: Comprehensive analysis of the damage and its impact on coastal zones by the 2004 Indian Tsunami Disaster. Report, disaster Prev. Res. Instit, Kyoto, Japan, available at: http: //www.tsunami.civil.tohoku.ac.jp/sumatra2004/report.html (last access: 10 August 2011), 2005.

Kerr, A. M. and Baird, A. H.: Natural Barriers to Natural Disasters, Bioscience, 57(2), 102-103, 2007.

Kerr, A. M., Baird, A. H., and Campbell, S. J.: Comments on "Coastal mangrove forests mitigated tsunami" by Kathiresan K. and Rajendran N. [Estuar. Coast. Shelf Sci., 65, 601-606, 2005], Estuarine, Coastal and Sheld Science, 67, 539-541, 2006.

KNMI web page: Tsunami Observations by the Echos Sounder on yacht Mercator, available at: http://www.knmi.nl/cms/content/ 4675/zeer_zware_aardbeving_en_tsunami_in_azie (last access: 10 August 2011), 2010.

Kongko, W., Leschka, S., Larsen, O., Gayer, G., Nöhren, I., and Günther, H.: A sensitivity test of tsunami modelling using various data: case study in Cilacap Indonesia, in: Proc. of the International Conference on Tsunami Warning (ICTW), Bali, Indonesia, 12-14 November, 2008.

Kotani, M., Imamura, F., and Shuto, N.: Tsunami run-up simulation and damage estimation by using GIS, Proc. of Coastal Eng., J. Soc. Civil. Eng., 45(1), 356-360, 1998.

Latief, H. and Hadi, S.: The role of forests and trees in protecting coastal areas against tsunamis, in: Coastal protection in the aftermath of the Indian Ocean Tsunami: What role for coastal forests and trees, in: Proceedings of the Regional Technical Workshop, edited by: Braatz, S., Fortuna, S., Broadhead, J., and Leslie, R., Khao Lak, Thailand, 28-31 August, 5-32, 2006.

Leschka, S., Pedersen, C., and Larsen, O.: On the requirements for data and methods in tsunami inundation modelling - Roughness map and uncertainties, in: Proc. of the South China Sea Tsunami Workshop, Penang, Malaysia, 3-5 November in press, 2009.

Liu, X., Sakai, S., Mikami, T., Iwama, S., Imamura, F., Shuto, N., and Kikuchi, H.: Numerical analysis on tsunami run-up and tsunami flood to a coastal city, in: Proceedings of the $28^{\text {th }}$ International Conference Coastal Engineering 2002, Solving Coastal Conundrums, Cardiff, Wales, 1, 116-1175, 2002.

Løvholt, F., Bungum, H., Harbitz, C. B., Glimsdal, S., Lindholm, C. D., and Pedersen, G.: Earthquake related tsunami hazard along the western coast of Thailand, Nat. Hazards Earth Syst. Sci., 6, 979-997, doi:10.5194/nhess-6-979-2006, 2006.

Mazda, Y., Magi, M., Kogo M., and Hong, P. M.: Mangroves as a coastal protection from waves in the Tong Kong delta, Vietnam,
Mangroves and Salt Marshes, 1, 127-135, 1997.

McCloskey J., Antonioli, A., Piatanesi, A., Sieh, K., Steacy, S., Nalbant, S., Cocco, M., Giunchi, C., Huang, J., and Dunlop, P.: Tsunami threat in the Indian Ocean from a future megathrust earthquake west of Sumatra, Earth Plan. Sci. Lett., 265, 61-81, 2008.

Mård Karlsson, J., Skelton, A., Sandén, M., Ioualalen, M., Kaewbanjak, N., Pophet, N., Asavanant, J., and von Matern, A.: Reconstructions of the coastal impact of the 2004 Indian Ocean tsunami in the Khao Lak area, Thailand, J. Geophys. Res., 114, C10023, doi:10.1029/2009JC005516, 2009.

Okal, E. A. and Synolakis, C. E.: Far-field tsunami hazard from mega-thrust earthquakes in the Indian Ocean, Geoph. J. Int., 172, 995-1015, 2008.

Petryk, S. and Bosmajian, G.: Analysis of flow through vegetation, J. Hydraul. Division, 101(7), 871-884, 1975.

Roemer, H., Kaiser, G., Sterr, H., and Ludwig, R.: Using remote sensing to assess tsunami-induced impacts on coastal forest ecosystems at the Andaman Sea coast of Thailand, Nat. Hazards Earth Syst. Sci., 10, 729-745, doi:10.5194/nhess-10-729-2010, 2010.

Rudloff, A., Lauterjung, J., Münch, U., and Tinti, S.: Preface "The GITEWS Project (German-Indonesian Tsunami Early Warning System)”, Nat. Hazards Earth Syst. Sci., 9, 1381-1382, doi:10.5194/nhess-9-1381-2009, 2009.

Schlurmann, T., Kongko, W., Goseberg, N., Natawidjaja, D. H., and Sieh. K.: Near-Field Tsunami Hazard Map Padang, West Sumatra: Utilizing High Resolution Geospatial Data and Reasonable Source Scenarios, in: Proceedings of the International Conference on Coastal Engineering, 32(2010), available at: http: //journals.tdl.org/ICCE/article/view/1100, 2011.

Shuto, N.: The effectiveness and limit of tsunami control forests, Coast. Eng. Jpn., 30, 143-153, 1987.

Spahn, H., Hoppe, M., Vidiarina, H. D., and Usdianto, B.: Experience from three years of local capacity development for tsunami early warning in Indonesia: challenges, lessons and the way ahead, Nat. Hazards Earth Syst. Sci., 10, 1411-1429, doi:10.5194/nhess-10-1411-2010, 2010.

Strusinska, A., Husrin, S., and Oumeraci, H.: Laboratory experiments on hydrodynamic performances of mangrove forest against tsunami impact, in: Proceedings of the 9th US National and 10th Canadian Conference on Earthquake Engineering, Paper no. 1857, Vancouver, Canada, 2010.

Suppasri, A., Koshimura, S., and Imamura, F.: Developing tsunami fragility curves based on the satellite remote sensing and the numerical modeling of the 2004 Indian Ocean tsunami in Thailand, Nat. Hazards Earth Syst. Sci., 11, 173-189, doi:10.5194/nhess11-173-2011, 2011.

Szczucinski, W., Chaimanee, N., Niedzielski, P., Rachlewicz, G., Saisuttichai, D., Tepsuwan, T., Lorenc, S., and Siepak, J.: Environmental and Geological Impacts of the 26 December 2004 Tsunami in Coastal Zone of Thailand - Overview of Short and Long-Term Effects, Pol. J. Environ. Stud., 15, 793-810, 2006.

Tanaka, N., Sasaki, Y, Mowjood, M. I. M., Jinadasa, K. B. S. N., and Homchuen, S.: Coastal vegetation structures and their functions in tsunami protection: experience of the recent Indian Ocean tsunami, Landscape Ecol. Eng., 3, 33-45, doi:10.1007/s11355006-0013, 2007.

Taubenböck, H., Goseberg, N., Setiadi, N., Lämmel, G., Moder, 
F., Oczipka, M., Klüpfel, H., Wahl, R., Schlurmann, T., Strunz, G., Birkmann, J., Nagel, K., Siegert, F., Lehmann, F., Dech, S., Gress, A., and Klein, R.: "Last-Mile" preparation for a potential disaster - Interdisciplinary approach towards tsunami early warning and an evacuation information system for the coastal city of Padang, Indonesia, Nat. Hazards Earth Syst. Sci., 9, 15091528, doi:10.5194/nhess-9-1509-2009, 2009.

Thailand Group, International Tsunami Survey Team of Indian Ocean Tsunami Disaster: The December 26, 2004 Sumatra Earthquake Tsunami, Thailand Field Survey around Phuket, Thailand, available at: www.drs.dpri.kyoto-u.ac.jp/sumatra/ thailand/phuket_survey_e.html (last access: 10 August 2011), 2005.

Titov, V. V. and Synolakis, C. E.: Modeling of breaking and non breaking long-wave evolution and run up using VTCS-2, J. Waterway Port Coast Ocean Eng., 121(6), 308-316, 1995.

Titov, V. V. and Synolakis, C. E.: Numerical modeling of tidal wave runup, J. Waterway Port Coast Ocean Eng., 124(4), 157-171, 1998.
Tsuji, Y., Namegaya, Y., Matsumoto, H., Iwasaki, S. I., Kanbua, W., Siriwchai, M., and Meesuk, V.: 2004 Indian tsunami in Thailand: Surveyed runup heights and tide gauge records, Earth Planets Space, 58(2), 223-232, 2006.

United Nations and World Bank: Tsunami Thailand, One year later, United Nations Country Team, Bangkok, 2005.

Weidner, U. and Lemp, D.: Objektorientierte Klassifizierung, in: Digitale Bildverarbeitung: Anwendungen in Photogrammetrie, edited by: Bähr, H. P. and Vögtle, T., Fernerkundung und GIS, Heidelberg, 160-122, 2005.

Wolanski, E.: Synthesis of the protective functions of coastal forests and trees against natural hazards, in: Proceeding of the Regional Technical Workshop on Coastal Protection in the Aftermath of the Indian Ocean Tsunami: What Role for Forests and Trees?, edited by: Braatz, S., Fortuna, S., Broadhead, J., and Leslie, R., Khao Lak, Thailand, 28-31 August, 161-183, 2007.

Yanagisawa, H., Koshimura, S., Goto, K., Miyagi, T., Imamura, F., Ruangrassamee, A., and Tanavud, C.: The reduction effects of mangrove forest on a tsunami based on field surveys at Pakarang Cape, Thailand and numerical analysis, Estuarine, Coastal Shelf Sci., 81, 27-37, 2009. 